\title{
Beyond Just Bacteria: Functional Biomes in the Gut Ecosystem Including Virome, Mycobiome, Archaeome and Helminths
}

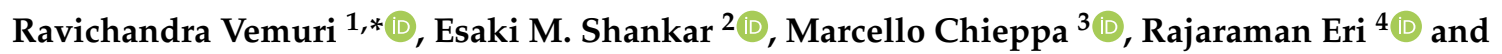 \\ Kylie Kavanagh ${ }^{1}$ D \\ 1 Department of Pathology, Section of Comparative Medicine, Wake Forest School of Medicine, \\ Medical Center Boulevard, Winston-Salem, NC 27157, USA; kkavanag@wakehealth.edu \\ 2 School of Basic and Applied Sciences, Central University of Tamil Nadu, Thiruvarur 610005, India; \\ shankarem@cutn.ac.in \\ 3 National Institute of Gastroenterology “S. de Bellis”, Research Hospital, 70013 Castellana Grotte (Bari), Italy; \\ transmed@irccsdebellis.it \\ 4 School of Health Sciences, College of Health and Medicine, University of Tasmania, Launceston 7248, \\ Australia; rajaraman.eri@utas.edu.au \\ * Correspondence: rvemuri@wakehealth.edu
}

Received: 6 March 2020; Accepted: 26 March 2020; Published: 28 March 2020

\begin{abstract}
Gut microbiota refers to a complex network of microbes, which exerts a marked influence on the host's health. It is composed of bacteria, fungi, viruses, and helminths. Bacteria, or collectively, the bacteriome, comprises a significant proportion of the well-characterized microbiome. However, the other communities referred to as 'dark matter' of microbiomes such as viruses (virome), fungi (mycobiome), archaea (archaeome), and helminths have not been completely elucidated. Development of new and improved metagenomics methods has allowed the identification of complete genomes from the genetic material in the human gut, opening new perspectives on the understanding of the gut microbiome composition, their importance, and potential clinical applications. Here, we review the recent evidence on the viruses, fungi, archaea, and helminths found in the mammalian gut, detailing their interactions with the resident bacterial microbiota and the host, to explore the potential impact of the microbiome on host's health. The role of fecal virome transplantations, pre-, pro-, and syn-biotic interventions in modulating the microbiome and their related concerns are also discussed.
\end{abstract}

Keywords: gut microbiota; virome; fecal virome transplants; mycobiome; archaeome; helminths

\section{Introduction}

The human gut contains a collection of microbes that include commensal, symbiotic, and pathogenic bacteria, as well as fungi, viruses, archaea, and helminths. Collectively, the microbes in the gut are known as gut microbiota, and their respective genomes are collectively known as the gut microbiome [1]. The normal human gut is unique to each individual and influenced by factors such as diet, early-life microbiota exposure, changing hygiene status, pollution, socioeconomic status, and other environmental factors [2,3]. During the past decade, the gut microbiota has been implicated as an essential factor in the pathogenesis of inflammatory bowel disease (IBD), cancer, cardio-metabolic diseases, obesity, and diabetes [2-6].

The human gut microbiome diversity is characterized in ecological terms by its species evenness (the number of different kinds of species present in an ecological community) and richness (the number of different species represented in an ecological community) [7]. Next-generation sequencing (NGS) revolutions enabling the 16S DNA-based quantitative identification of enteric bacteria sparked 
numerous microbiome-wide studies that correlated gut bacterial diversity and its composition shifts, termed as 'dysbiosis', with human disease [8]. Most of the available research literature on the microbiome has focused on bacteria or bacteriome but not the other components [4]. The number of studies on the gut microbiome (many correspond to bacteriome only) have skyrocketed, reaching up to 3500 papers in 2018 (Figure 1) (Supplemental Table S1). Although bacteria dominate microbial communities, viruses, archaea, and fungi may also play pivotal roles in maintaining the gut homeostasis [9], as evidenced by a more recent steep increase in studies assessing the role of viral and fungal components of the microbiome. However, the viral and fungal biomes remain relatively uncharacterized thus far, due to their lower abundance as well as lack of optimized tools and curated reference databases for their identification and classification $[10,11]$.

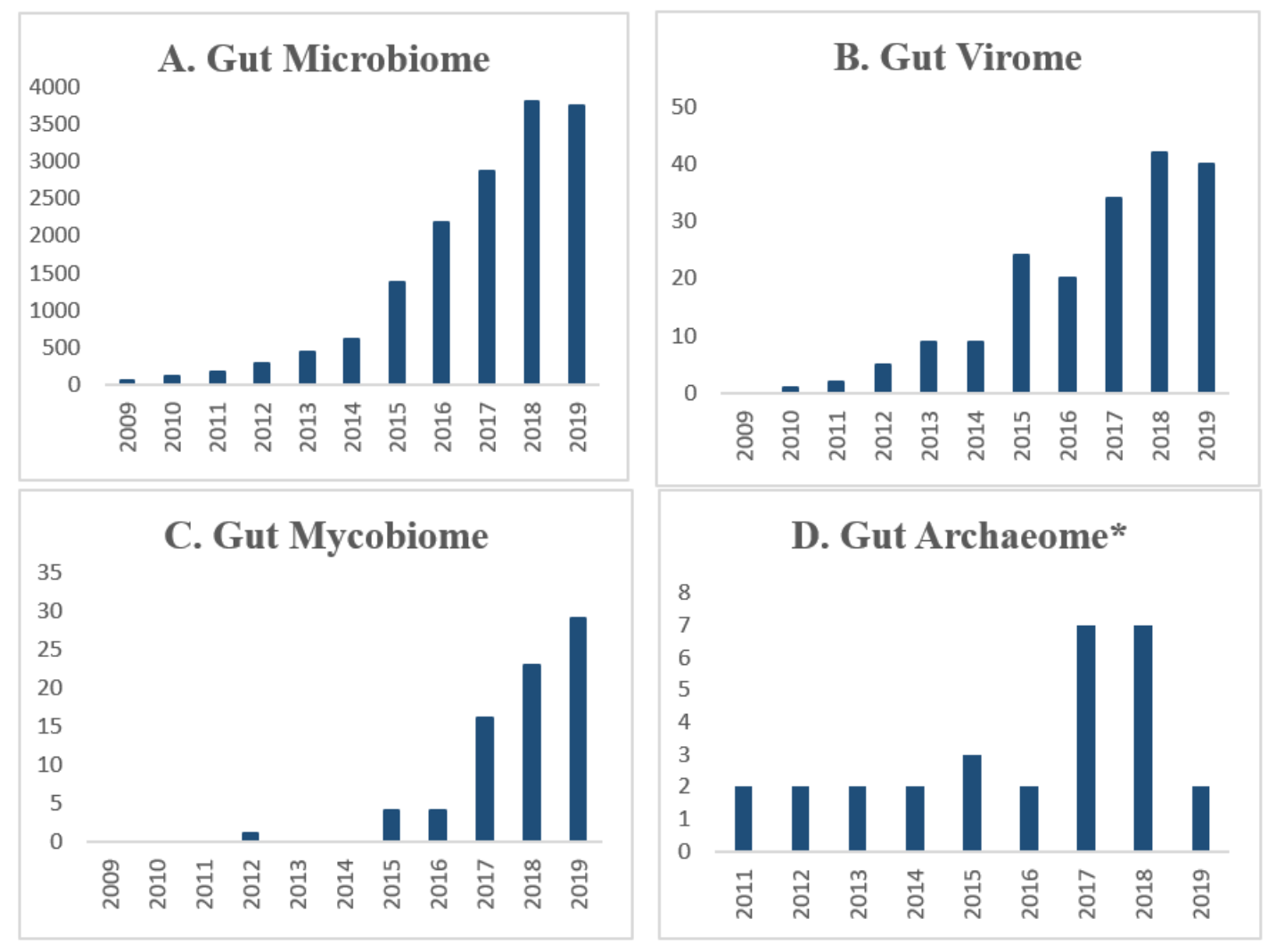

Figure 1. Scientific publications on various microbial communities of the gut microbiome. The number of peer-reviewed scientific publications for (A) microbiome, (B) virome (C) mycobiome and (D) archaeome studies. The list of peer-reviewed literature was collated in a non-systematic manner from the web of science (WOS) all database collection (MEDLINE, Inspec, Biological abstracts, scIELO, KCI, WOS core collection, Russian science index) from 2009 to 2019. The research of literature was performed using keywords like "microbiome", "gut microbiome", "gut virome", "virome", "gut fungi”, and "gut mycobiome". * For careful selection of gut archaeome studies, we used PubMed only with keywords like "gut archaea", "gut archaeon" and "gut archaeome/archaeon" and "archaeome" which includes whole microbiome analysis studies but not limited to only archaeome. Document types excluded were review of the literature (including systematic and meta-analysis), case studies, reports, and abstracts in conferences, workshops, and book chapters.

Owing to advances in NGS technologies, researchers are now starting to understand the dark matter of the microbiota as summarized in Table 1. Emerging studies indicate that the gut virome mainly includes DNA or RNA bacteriophages [12]. In addition, fungi, which primarily comprises Aspergillus, Candida, Fusarium, Penicillium, and Saccharomyces [13], and likewise gut archaea, especially methanogens [14], represent notable members of the microbiome. Data on the role of helminth species 
in human health is very limited and more population-based studies are required to evaluate their role in the gut $[15,16]$. Clearly, though, viruses, fungi, archaea, and helminths also comprise a significant composition of the gut ecosystem, and their existence could account for host-microbe interactions [12]. In this review, we used human and animal studies to discuss gut virome, mycobiome, archaeome, helminths, and their interaction and health impacts.

Table 1. Summary of a few significant clinical studies on the viral, fungal, and archaeal microbiomes.

\begin{tabular}{|c|c|c|c|c|}
\hline $\begin{array}{l}\text { Microbial } \\
\text { Component }\end{array}$ & Samples & $\begin{array}{l}\text { Sorting/Analysis } \\
\text { Method }\end{array}$ & Reads/Contigs */Sequences & Ref. \\
\hline \multirow{3}{*}{ Viral } & 21 & $\begin{array}{l}\text { Hidden Markov } \\
\text { Models/STAR }\end{array}$ & \multirow{3}{*}{$\begin{array}{c}\text { Assembled: } 107,307 \text { contigs. } \\
\text { Total taxonomically assigned: } 12,751 \text { contigs } \\
\text { ( } 29.62 \% \text { only) } \\
\text { Assembled: } 294,211 \text { contigs } \\
\text { Alignment of reads to contigs: } 57,721 \\
\text { Final catalogue: } 39,254 \text { contigs } \\
\text { Total reads: } 1,386,331 \text { (32 datasets) } \\
\text { Date normalized: } 14,000 \text { reads/dataset } \\
\text { Annotated yield: } 5004 \text { contigs }\end{array}$} & [17] \\
\hline & 10 & & & [18] \\
\hline & 32 & CD-Hit-est & & [19] \\
\hline \multirow{3}{*}{ Fungal } & $\begin{array}{c}317 \\
\text { (147 subjects) }\end{array}$ & $\begin{array}{l}\text { Internal Transcribed } \\
\text { Spacer } 2 \text { (ITS) }\end{array}$ & \multirow{3}{*}{$\begin{array}{c}\text { Total reads per } 1 \text { sample/subject: } 756,316 \text { reads } \\
\text { Total reads/sample: } 17,189 \\
\text { IonPGM: } 219,756 \text { reads } \\
\text { MiSeq: } 181,436 \text { reads } \\
\text { PacBio: } 2984 / \text { sample } \\
\text { Total: } 41,776 \text { reads } \\
\text { 106,185 reads }\end{array}$} & [20] \\
\hline & 14 & $\begin{array}{l}\text { ITS1 (IonPGM, MiSeq, } \\
\text { PacBio Sequence } \\
\text { comparisons) }\end{array}$ & & [21] \\
\hline & 49 & ITS & & [22] \\
\hline \multirow{3}{*}{$\begin{array}{c}\text { Archaeal } \\
\text { (Methanogens) }\end{array}$} & 21 & & 1521 sequences & [23] \\
\hline & 10 & & 10,000 reads/sample & [24] \\
\hline & 49 & & 109,561 reads & [22] \\
\hline
\end{tabular}

${ }^{*}$ Contigs $=$ either a DNA segment or set of overlapping DNA sequences.

\section{Gut Virome}

The bacterial and fungal communities residing in the gastrointestinal (GI) tract have undeniable far-reaching effects in regulating host health [1,12]. In contrast, the composition and dynamics of the gut virome are largely unknown, mainly due to limitations in identification. This is likely because of the lack of availability of viral genomes in the NCBI databases due to diverse global viral populations and their size. However, the impediments to identify and classify the virome have been now overcome with advancements in NGS, allowing us to make more substantial analyses of viromes [25]. Bioinformatics tools, such as the Metavir (versions 1 and 2) [26], bioinformatics pipeline VIROME (Viral Informatics Resource for Metagenome Exploration) [27], VIROMEScan [28], PHACCS (Phage Communities from Contig Spectrum) [29], CLAssification of Mobile genetic Elements (ACLAME) [30], VirusSeeker [31], the Phage SEED, and OptItDBA (Optimized Iterative de Bruijn Graph Assembly) have greatly improved the breadth and accessibility of virome analysis by improving assembly and annotating viromes against multiple annotated sequence databases, which improves the analytic capabilities beyond the constraints of individual sequence databases [32,33].

\subsection{Gut Phages}

The gut virome includes diverse commensal and pathogenic viruses that have abilities to infect host cells as well as other microbes, both avenues are able to directly affect the host's health (Table 2). With a high inter-individual variation, the gut virome is mostly dominated by bacteriophages [34]. It also includes prophages, eukaryotic viruses, and retroviruses (Table 3). Very recently, studies on metagenomic sequencing of fecal DNA have begun to consistently unravel the extremely complex composition of the gut virome [10,35]. The DNA and RNA viruses that collectively make up the gut virome are at least comparable in number to bacterial cells, but on the gut mucosal surfaces and within the mucous layers; they may outnumber bacterial cells by 20:1 [36,37]. Each gram of human gut content is estimated to contain at least $10^{8}-10^{9}$ virus-like particles, the vast majority of which are 
cross-assembly phage (DNA) phages belonging to the family Podoviridae $[38,39]$. Several studies have characterized the gut phage communities in newborn children, demonstrating a high richness and diversity and low stability during the initial days of life $[17,40]$. This diversity diminishes over the first two years, contrary to what has been observed in bacterial populations, which shift from low to high diversity [41]. Gut phages are primarily classified as members of the double-stranded (ds) DNA virus families such as Myoviridae, Podoviridae, and Siphoviridae within the order Caudovirales, or of the single-stranded (ss) DNA Microviridae family [12]. Recognizing the high abundance of phages in the gut, a Bacteroidetes-infecting phage family was identified and its founding phage alone represented up to $22 \%$ of all reads in the human gut metagenome project [42]. Another study characterizing Microviridae from healthy human donors also clustered with the Bacteroides and Prevotella prophages 72 , suggesting that Microviridae could be an important viral family in the human gut. These prophages are considered lytic phages, which can integrate into bacterial hosts in an environment that encourages a temperate (lysogenic) viral-host lifestyle [39,41,43]. 
Table 2. Summary of significant study findings on the gut virome.

\begin{tabular}{|c|c|c|c|}
\hline Model Type & Study Type & Findings & Ref \\
\hline \multicolumn{4}{|c|}{ Human } \\
\hline Healthy infant & 1 week old infant $\mathrm{N}=1$ & Taxa identified: Siphoviruses and prophages (the majority $(72 \%)$ & [41] \\
\hline \multirow{3}{*}{ Infants/mothers (healthy) } & $\begin{array}{l}\text { Healthy adult female monozygotic co-twins and their } \\
\text { mothers at three time points over a one-year period } \mathrm{N}=12\end{array}$ & $\begin{array}{c}\text { Eukaryotic viral genomes: } 73.3 \% \text {, phages and prophages: } 25.8 \% \\
\text { dsDNA phage (Caudovirales): } 76.9 \%\end{array}$ & [19] \\
\hline & $\mathrm{N}=8$ (4 twin pairs) & $\begin{array}{l}\text { Taxa identified: Siphoviridae, Inoviridae, } \\
\text { Myoviridae and Podoviridae }\end{array}$ & [43] \\
\hline & $\mathrm{N}=24$ longitudinal fecal samples & $\begin{array}{l}\text { Taxa identified: Microviridae, Podoviridae, } \\
\text { Myoviridae, and Siphoviridae }\end{array}$ & [44] \\
\hline $\begin{array}{l}\text { Healthy vs. malnourished } \\
\text { infants/children }\end{array}$ & $\begin{array}{l}\text { Time-series from fecal samples (Malawian) healthy control } \\
\qquad(\mathrm{HC})=\text { twins, Mal Nutr }=12 \text { twin pairs }\end{array}$ & $\begin{array}{l}\uparrow \text { Anelloviridae (ssDNA eukaryotic viruses) in healthy infants and } \\
\text { children (up to } 15-18 \text { mo), With age: } \uparrow \text { Alpavirinae (ssDNA phages), } \\
\uparrow \text { Siphoviridae in } 0 \text { to } 10 \text { mo of age and then slowly decrease. }\end{array}$ & [45] \\
\hline Obese children & $\mathrm{N}=20(\mathrm{HC}=10$, Obese $=10)$ & Obese to HC: $\uparrow$ Human herpesvirus 4 & [46] \\
\hline \multirow{3}{*}{ Human (Healthy) } & $\begin{array}{l}\text { Longitudinal metagenomics analysis (Ireland) of fecal } \\
\text { viruses } N=6 \text { (3 Males, } 3 \text { Females) }\end{array}$ & $\begin{array}{l}\text { Taxa identified: } \uparrow \text { Virulent crAss-like and } \\
\text { Microviridae bacteriophages }\end{array}$ & [18] \\
\hline & Uncultured viral community from human feces. $\mathrm{N}=1$ & $\begin{array}{l}\text { Taxa identified: Bacteriophages A118 of Listeria monocytogenes, } \\
\text { E125 of Burkholderia thailandensis, and bIL285 of Lactococcus lactis }\end{array}$ & [47] \\
\hline & Analysis of the RNA viruses $(\mathrm{N}=2)$ & $\begin{array}{c}\text { Pepper mild mottle virus }=10^{9} \text { virions/gram of dry fecal matter, } \\
\uparrow \text { RNA viruses }\end{array}$ & [48] \\
\hline Virome of the ELDERMET & First-ever in elders (>65 yrs) & Taxa identified:Gokushovirinae (Microviridae) & [49] \\
\hline Diet variations & sequencing $(N=6)$ high-fat/low-fiber diet & $\begin{array}{l}\text { High fat to low fiber: Siphoviridae (18\%), } 686(10 \%) \text { to Myoviridae, } \\
344(4.8 \%) \text { to Podoviridae, } 68(0.9 \%) \text { to Microviridae, and } 0.4 \% \text { others }\end{array}$ & [50] \\
\hline \multirow{2}{*}{ Human Virome (IBD) } & $\begin{array}{l}\text { Virus-like particle preparations on the rectal mucosa } \\
\qquad(\mathrm{N}=167,(\mathrm{UC}=91 ; \mathrm{HC}=76)) \text {. (Chinese study) }\end{array}$ & $\begin{aligned} \text { UC to HC }= & \downarrow \text { mucosal Caudovirales diversity, richness } \\
& \text { and evenness relative to HC }\end{aligned}$ & [51] \\
\hline & $\begin{array}{l}\text { metagenomics sequencing of stool filtrates using the Roche } \\
454 \text { platform (UK) }\end{array}$ & $\begin{array}{l}\text { The viromes of CD and UC patients were disease- and } \\
\text { cohort-specific. } \uparrow \text { Caudovirales bacteriophages compared to HC }\end{array}$ & [52] \\
\hline
\end{tabular}


Table 2. Cont.

\begin{tabular}{|c|c|c|c|}
\hline T2D vs. HC & $\begin{array}{c}\text { Type II diabetes (T2D) patients }(n=71) \text { and normal } \\
\text { Chinese adults }(\mathrm{HC}) n=74) \text {. }\end{array}$ & $\begin{array}{c}\text { T2D to HC: } \uparrow \text { phages (Siphoviridae }(55.3 \pm 9.8 \%) \text { Myoviridae } \\
(21.7 \pm 9.9 \%), \text { Podoviridae }(10.6 \pm 8.4 \%))\end{array}$ & [53] \\
\hline HIV study & $\begin{array}{c}(\mathrm{N}=122, \text { untreated } \mathrm{HIV}=42, \mathrm{HIV} \text { ART }=40, \\
\text { HIV uninfected }=40)\end{array}$ & HIV to uninfected: $\uparrow$ Anelloviridae, Adenoviruses & [54] \\
\hline \multicolumn{4}{|c|}{ Animal } \\
\hline $\begin{array}{l}\text { Gorilla simian } \\
\text { immunodeficiency virus } \\
\text { infection (SIV). }\end{array}$ & $(\mathrm{N}=22, \mathrm{SIV}=11, \mathrm{HC}=11)$ & $\begin{array}{l}\text { SIV to HC: } \uparrow \text { Herpesviridae and Reoviridae } \\
\text { Identified: Siphoviridae, Myoviridae and Podoviridae }\end{array}$ & [55] \\
\hline \multirow{3}{*}{ Rodents } & $\mathrm{N}=314$ wild rodent & Taxa identified: Parvovirus, Dicistrovirus, Iflavirus, and Iridovirus & [56] \\
\hline & viral RNA and DNA in the feces of 105 wild rodents & $\begin{array}{c}\text { Taxa identified:Circoviridae, Picobirnaviridae, Picornaviridae, } \\
\text { Astroviridae, Parvoviridae, Papillomaviridae, } \\
\text { Adenoviridae, and Coronaviridae. }\end{array}$ & [57] \\
\hline & viral content in rat fecal matter $(\mathrm{N}=29)$ & Picornaviridae & [58] \\
\hline Mouse & $\mathrm{N}=416$ mice & $\begin{array}{c}\text { Taxa identified: Parvovirinae, Chapparvovirus, Polyomavirus, } \\
\text { Astroviruses, Sapovirus, Picornavirus }\end{array}$ & [59] \\
\hline Mouse model of IBD & $\begin{array}{l}\text { C57BL6/J mice (HC) and C57BL6/J Rag1- } \\
\text { mice (IBD induced) }\end{array}$ & IBD to $\mathrm{HC}=\uparrow$ Spounaviridae, $\downarrow$ Clostridiales phages & [60] \\
\hline $\begin{array}{l}\text { Gulf War illness (GWI) } \\
\text { mouse model (IBD) }\end{array}$ & $(\mathrm{N}=22, \mathrm{HC}=11, \mathrm{GWI}=11)$ & $\begin{aligned} \text { GWI mice to HC } & =\downarrow \text { Microviridae bacteriophages, } \uparrow \text { Siphoviridae } \\
& \text { and Myoviridae bacteriophages }\end{aligned}$ & [61] \\
\hline $\begin{array}{l}\text { Gnotobiotic mouse model } \\
\text { of phage-bacterial host } \\
\text { dynamics }\end{array}$ & $(\mathrm{N}=5$ per group $)$ & $\begin{array}{l}\text { T7 phages are undetectable for } 1 \mathrm{wk} \text { in germ-free animals before they } \\
\text { rise in abundance after gavage of a bacterial host. }\end{array}$ & [62] \\
\hline
\end{tabular}

$\uparrow$ increase; $\downarrow$ decrease; $\mathrm{HC}=$ healthy control; IBD = inflammatory bowel disease; ss = single stranded; T2D = type 2 diabetes. 
Table 3. Viral communities identified in the mammalian gut.

\begin{tabular}{|c|c|c|c|c|}
\hline Phages & ds DNA & ss DNA & ds RNA & ss RNA \\
\hline Microviridae & Papillomaviridae & Circoviridae & Reoviridae & Retroviridae \\
\hline Podoviridae & Polyomaviridae & Anelloviridae & & Togaviridae \\
\hline \multirow{4}{*}{ Siphoviridae } & Poxviridae & & & Astroviridae \\
\hline & Adenoviridae & & & Virgaviridae \\
\hline & Iridoviridae & & & Caliciviridae \\
\hline & Marseilleviridae & & & \\
\hline
\end{tabular}

ds = double stranded; ss = single stranded.

\subsection{Enteric Viruses}

While the number of eukaryotic viruses present in the gut is lesser than that of phages, they are detected in metagenomic studies by PCR-based fecal shedding analyses in healthy individuals $[45,63]$. For example, viruses from the Anelloviridae, Picobirnaviridae, Adenoviridae, and Astroviridae families and species such as Bocavirus, Rotavirus, Enterovirus, and Sapovirus were identified in the fecal DNA samples of healthy children [41,45]. As the presence of eukaryotic viruses in the gut is far less well characterized, some studies have shed light on the dynamics of these viruses, with at least 16 different DNA viral families and 10 RNA families having been detected in gut samples [64]. These observations demonstrate that intestinal colonization with eukaryotic viruses, some of which are known to have pathogenic potential, can be tolerated without apparent symptomatic disease.

\subsection{Role of the Gut Virome in Gastrointestinal Health and Disease}

When considering the role of the enteric virome in the pathophysiology of GI diseases, the bridge from association to causation needs to be crossed. The gut virome, including enteric eukaryotic viruses and bacteriophages, can elicit chronic inflammation by infecting and killing the host cell as well as bacteria [65]. The first gut virome studies linked the presence or absence of certain viral components to diseases such as IBD and type 1 diabetes (T1D) $[9,66]$. The decreasing richness of gut bacteria occurring with IBD (both Crohn's disease (CD) and ulcerative colitis (UC)) patients is well established [2]. In contrast, the fecal virome component's richness was increased in those disease states when compared to healthy controls $[67,68]$. Specifically, the number of Caudovirales bacteriophages were increased and associated with viral richness relative to healthy controls $[66,68]$. Similar results were reported by another study that found reduced Caudovirales phages in healthy individuals when compared to CD and UC patients [51]. Studies of viral communities of diarrheic specimens for unknown causes in individuals from the Americas and Europe resulted in finding a common group of viruses that included Anelloviruses, Picobirnaviruses, and Aichivirus [69,70]. The role of these viruses, as well as if their presence is the cause or a consequence of a diseased GI tract, remains undetermined. In contrast to the richer gut virome observed in IBD patients, the gut viromes of individuals developing T1D were found to be less diverse than the ones from healthy controls, with the latter harboring significantly more viruses of the Circoviridae family [67], suggesting that viruses in the GI tract, such as Circoviridae in T1D, may alternatively exert beneficial functions for preserving host health [71].

\subsection{Viromes in Fecal Microbial Transplants and Fecal Virome Transplants}

Fecal microbiota transplantation (FMT) has played a significant role in treating recurrent Clostridium associated diarrhea. FMT or a nature-tailored probiotic treatment appears to restore normal or donor-like gut microbial (specifically bacterial) diversity. However, understanding the complex nature of gut microbiome, investigation into the presence and contribution of viromes in such fecal transplants has also begun, shown in Table 4. It is now certain that fecal microbiota contains a high abundance of viruses, primarily bacteriophages $(90 \%)$ helping to repopulate gut bacterial diversity. As discussed, phages outnumber bacteria on mucosal surface and concerns persist about the unwanted transfer of pathogenic viruses from donor to recipient. The findings from a study by Chehoud and colleagues 
on FMT treatment in children with UC confirmed the transfer of viral-like particles [72]. Specifically, the members of Siphoviridae (temperate phages) were transferred with greater efficiency; however, none of the viral groups infected human cells. Zuo et al. investigated the presence and role of virome in patients with C. difficile infection (CDI) [73]. This particular study [73] confirmed the presence of phages from Caudovirales (tailed bacteriophages) before FMT treatment, but lower diversity, richness, and evenness compared to healthy controls. More recently, it was found that the impact of a successful FMT on the virome lasted for 12 months and resultant colonization of specific phages depended on donor-recipient combination [74]. This is consistent with a pilot study in which FMT devoid of bacteria was effective in CDI treatment, and increases the possibility that phages may be involved in the success of FMT [75].

In line with the studies mentioned above [75], a few researchers have recently developed a novel therapeutic intervention known as fecal virome transplantation (FVT), where only the viral component from FMT is transplanted [76-78]. Draper et al. confirmed the role of the virome in health and disease and showed that FVT, primarily consisting of phages, ameliorated antibiotic-induced bacterial dysbiosis [74]. FVT in mice resulted in a significant impact on not only abundance and diversity of bacteriome, but also the virome. The transplanted phages were able to colonize the gut and reshape the bacteriome similarly to a pre-antibiotic state. Likewise, a study by Rasmussen et al. utilized FVT in a type-2-diabetes and murine-obesity model [78], whereby only the virome in transplants from lean mice fed with a low-fat diet (LFD) to both obese mice (diet-induced obesity (DIO)) and mice fed a high-fat diet (HFD) + antibiotics, unlike Turnbaugh et al. [79]. FVT from lean donors partially reshaped the gut microbial composition in both of the recipient groups and decreased weight gain in DIO mice. In both these FVT studies [78], the gut viral composition was dominated by order Caudovirales and family Microviridae viruses. In another study, treatment with FVT (lytic and temperate gut phages) modulated gut microbial composition; the lytic phages enhanced the beneficial species of gut microbiota, and temperate phages stimulated the growth of commensal in the gut [76]. Interestingly, Hsu et al. confirmed that phages not only modulate the microbiome but also its associated metabolome [80]. In this particular study [80], gnotobiotic mice were subjected to lytic phages (FVT) after they were colonized with commensals, resulting in the finding that phage-led microbiome modulation was indeed due to intense microbe-microbe (intra- and inter-microbial) interactions which led to changes in the metabolome. More recently, Lin et al. compared FVT against FMT treatment on the ileal microbiome in mice fed with HFD [77], which promoted small intestinal bacterial overgrowth. They found reduced bacterial diversity in HFD mice receiving either FMT or FVT, compared to controls. Moreover, fecal transplants to control mice from HFD donor mice subjected to FVT shifted the ileal microbial composition similar to HFD mice, suggesting a causative role for FVT. Indeed, virome transplants could be beneficial as a therapy for many metabolic diseases related to gut microbiota, in addition to recurrent CDI.

Table 4. Summary of studies and their findings involving in viromes from fecal microbial transplantations (FMT).

\begin{tabular}{|c|c|c|c|}
\hline Model & Study Details & Findings & Ref. \\
\hline Infant IBD & $\begin{array}{l}\mathrm{N}=4, \text { Infant } \mathrm{UC}=3, \mathrm{HC}=1 \\
(22 \text { to } 30 \text { FMT treatments }\end{array}$ & UC to HC: $\uparrow$ Siphoviridae & {$[72]$} \\
\hline Adult IBD & $\mathrm{N}=15, \mathrm{UC}=9, \mathrm{HC}=8$ & $\begin{array}{l}\text { UC to HC: } \downarrow \text { DNA phage, } \\
\text { richness of donor viromes } \neq \text { outcome of therapy } \\
\text { Most abundant: Anelloviridae, Circoviridae, } \\
\text { Picobirnaviridae and Virgaviridae }\end{array}$ & [81] \\
\hline $\begin{array}{l}\text { Clostridium difficile } \\
\text { infection (CDI) }\end{array}$ & $\mathrm{N}=44, \mathrm{CDI}=24, \mathrm{HC}=20$ & $\begin{array}{c}\text { CDI to HC: } \uparrow \text { Caudovirales (may play a role in FMT } \\
\text { efficacy in CDI) }\end{array}$ & [73] \\
\hline $\begin{array}{l}\text { Recurrent CDI (rCDI) } \\
\text { 1-year follow-up }\end{array}$ & $\mathrm{rCDI}=14 ;$ donors $(\mathrm{D})=3$ & $\begin{array}{l}\text { rCDI to D: } \uparrow \text { Caudovirales, } \\
\text { Anelloviridae } \downarrow \text { Microviridae }\end{array}$ & {$[74]$} \\
\hline
\end{tabular}




\section{Mycobiome}

Mycobiome, mycome, fungeome, or mycobiota is the collection of the fungal community and their respective genomes associated with the human body. Fungi are detected within the gut of many mammals, including humans, mice, rats, pigs, and numerous ruminant and non-ruminant herbivores [82]. NGS of the internal-transcribed-spacer (ITS) regions to identify the fungal ribosomal genes indicated the mycobiome as a third important dimension of the gut microbiomes [20]. However, the characterization of the mycobiome is complicated by the lack of comprehensive, accurate, and high-resolution taxonomic annotation within fungal databases [83]. Existing databases containing fungal targets include UNITE fungal ITS (1 and 2) database [84], Findley, ITSoneDB, RefSeq targeted loci (RTL), targeted host-associated fungi (THF) database, International Society for Human and Animal Mycology (ISHAM) ITS database, and SILVA [83-91]. The bioinformatics tools used in data analyses include MaAsLin [92] and MEGA software [93].

Several studies in recent years have detailed the importance of fungi within the human gut (Table 5) [82]. Shotgun metagenomics sequencing approaches suggest that fungi account for approximately $0.1 \%$ of the gut microbiome. An early study by Quin and colleagues that included 96 stool samples from healthy volunteers found 66 genera [94]. Fungi are detectable in all sections of the GI tract of about $70 \%$ of healthy adults, normally at up to $103 \mathrm{cfu}$ per $\mathrm{mL}$ or $\mathrm{g}$ of intestinal contents [82]. Fungal genera commonly detected in mycobiome include Candida, Saccharomyces, Fusarium, Debaromyces, Penicillium, Galactomyces, Pichia, Cladosporium, Malassezia, Aspergillus, Cryptococcus, Trichosporon, and Cyberlindnera [95]. The potential roles played by these microbes in the human gut, however, is poorly understood.

Recent findings support the notion that a competitive association exists between bacterial and fungal microorganisms in the gut [6]. As an example, studies have shown that prolonged antibiotic usage is linked to fungal infection and overgrowth, particularly in the gut, and that germ-free mice are susceptible to infection with fungi such as Candida spp. [96]. Mycobiome dysbiosis is relevant in diseases such as IBD; the gut mycobiome of IBD patients has been characterized by reduced fungal diversity and a dysbiosis in community populations relative to healthy controls [97]. At the phylum level, the fungal ratio of Basidiomycota to Ascomycota was altered, with significantly higher relative abundance of Basidiomycota and a corresponding lower abundance of Ascomycota. More specifically, these trends have been attributed to higher relative abundances of the taxa Candida, Filobasidiaceae, and Malasseziales and a concurrent lower abundances of Saccharomyces, Penicillium, and Kluyveromyces [82,95].

Some emerging factors thought to be associated with composition of the mycobiota include host genotype and host physiology, including sex, age, and presence of comorbid conditions, lifestyles such as diet, hygiene, and occupation, and the immune system [98]. Diet represents a significant factor influencing the fungal mycobiome composition $[6,99]$. For example, Candida abundance is found to be strongly associated with the recent ingestion of carbohydrates [100]. However, further research is needed to establish the causality and explore the importance of additional factors that may influence the mycobiota, such as other lifestyle factors (e.g., exercise), medications (e.g., antibiotics or antifungals), and comorbid conditions. 
Table 5. Summary of significant studies and their findings on the gut mycobiome.

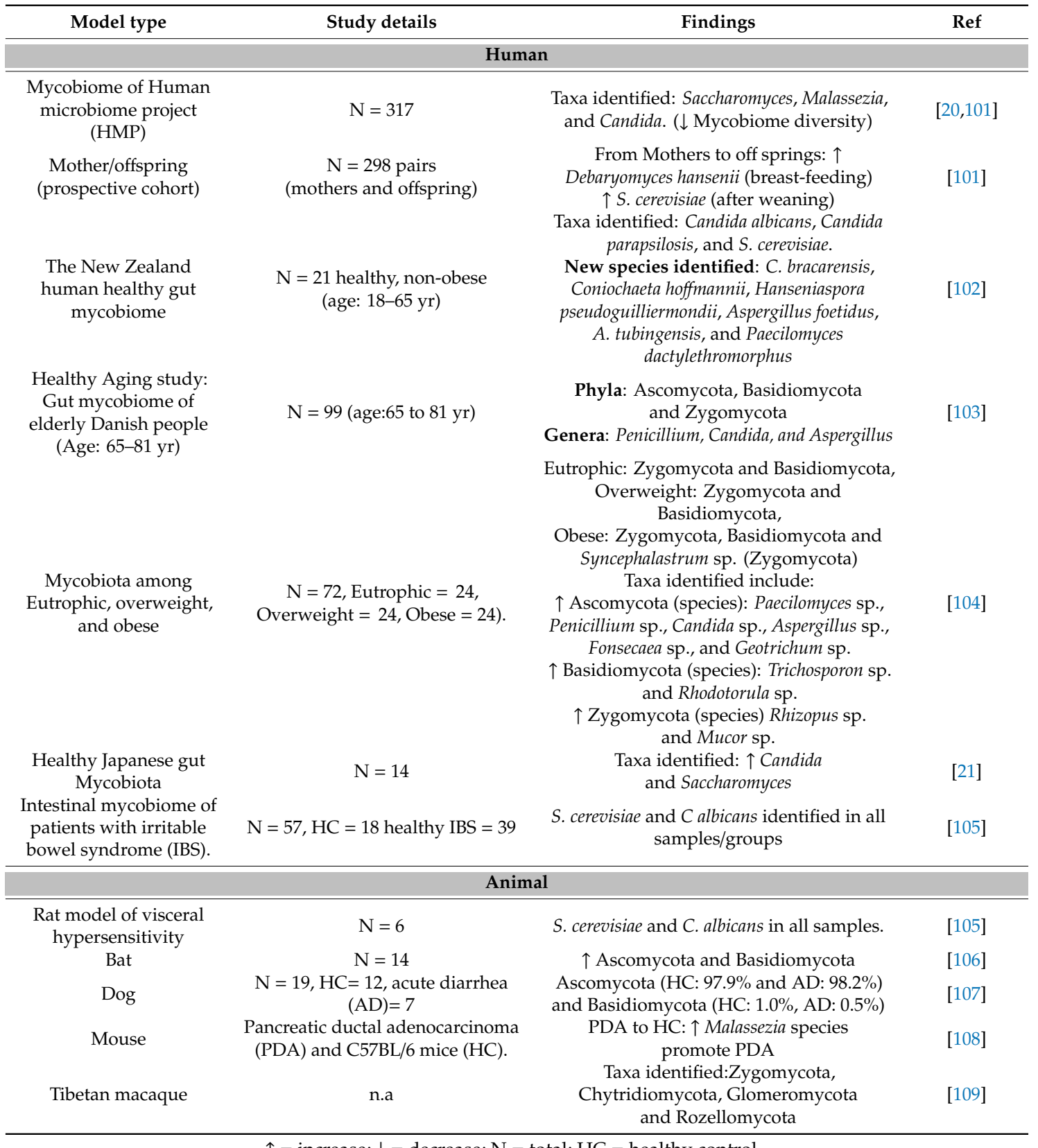

$\uparrow=$ increase $; \downarrow=$ decrease; $\mathrm{N}=$ total; $\mathrm{HC}=$ healthy control.

\section{Gut Archaea}

Like bacteria, archaea are prokaryotes and categorized under the single-cell domain. Although morphologically they resemble bacteria, archaea have genes and metabolic pathways like other eukaryotes. The archaeal part of the gut microbiome is referred to as archaeome (Table 6). A range of human fecal NGS studies worldwide has reported archaeal prevalence up to 0.8 to $0.10 \%$ of the whole gut microbiome $[5,94,110]$. The most prominent archaeal microbes are methanogens (methane producers) and less prominent are halophilic (salt-loving microbes) archaea [110]. Molecular studies have indicated the presence of members of the orders Methanosarcinales, Thermoplasmatales, Methanomicrobiales, and Nitrososphaerales in the human gut microbiota; however, to date these microbes have not been isolated [14,111].

Methanogens are strict anaerobes that belong to the order Methanobacteriales, the most common genera being the closely related Methaonbrevibacter and Methanosphaera [110,112]. The abundance 
of methanogens increases from $0.03 \%$ to $11 \%$ of total gut microbes present between the proximal and distal colon [112]. M. smithii produces methane from the byproducts of bacterial fermentation and is present in up to $95 \%$ of fecal samples from human subjects [113]. Interestingly, M. smithii's abundance was found to be stable over time, even after major changes in diet $[14,114]$. In the human gut, methanogenic archaea may impact host metabolism, especially energy homeostasis and may contribute to obesity [79], by syntrophic interactions with gut bacteria, which increase short-chain fatty acid production and contribute to an excess of calories available to the host [115]. Moreover, methanogens produce methane, shown to slow intestinal transit and lead to constipation [116]. In the case of IBD, methanogens like M. smithii and Methanosphaera stadtmanae have been most prevalent and shown to induce strong pro-inflammatory responses via monocyte-derived dendritic cells [117-119]. Halophilic archaea, or halophiles, are salt-loving microbes; the human gut environment is moderately salty, and a few IBD studies have isolated halophilic archaea from intestinal mucosal samples [120]. Currently, the studies on archaeal association with human disease are limited and further investigation is needed to elucidate its role in human health.

Table 6. Significant studies and their findings on the gut archaeome.

\begin{tabular}{|c|c|c|c|}
\hline Model type & Study details & Findings & Ref \\
\hline \multicolumn{4}{|c|}{ Human } \\
\hline Healthy infants & $\begin{array}{c}N=15, \text { Cesarean section-delivered } \\
(\mathrm{CSD})=8, \text { Vaginally-derived }(\mathrm{VD})=7\end{array}$ & CSD to VD: $\uparrow$ Methanosphaera spp. & {$[121]$} \\
\hline Infants/mothers (healthy) & $\mathrm{N}=8(4$ twin pairs $)$ & Lipothrixviridae & [43] \\
\hline Obese children & $\mathrm{N}=20(\mathrm{HC}=10$, Obese $=10)$ & Obese to HC: $\uparrow$ Methanobrevibacter spp. & [46] \\
\hline & $\mathrm{N}=476$ & Obese to HC: $\uparrow$ M. smithii & [122] \\
\hline \multirow{2}{*}{ Healthy adults } & $\mathrm{N}=8$ & M. smithii (99-100\%) & [123] \\
\hline & $\mathrm{N}=15($ Finnish $)$ & $\begin{array}{c}\text { Taxa identified: } \\
\text { Methanobrevibacter-specific }\end{array}$ & {$[124]$} \\
\hline Population-based & $\begin{array}{l}\text { Belgian Flemish Gut Flora Project } \\
\text { (FGFP; discovery cohort; N = 1106) } \\
\text { and the Dutch LifeLines-DEEP study } \\
\text { (LLDeep; replication; } N=1135 \text { ) }\end{array}$ & $\begin{array}{l}\uparrow \text { Methanobrevibacter spp. } \\
\text { in all samples }\end{array}$ & {$[125]$} \\
\hline Aging study & $\mathrm{N}=500$ & $\begin{array}{c}\text { Taxa identified: M. smithii } \\
\text { Methanosphaera stadtmanae } \\
\text { Methanomassiliicoccus luminyensis }\end{array}$ & {$[126]$} \\
\hline Archaea of ELDERMET study & $\mathrm{N}=371$ & $\begin{array}{l}\text { Taxa identified: } \\
\text { Methanomassiliicoccales }\end{array}$ & {$[127]$} \\
\hline Type 2 diabetes & $\begin{array}{c}\mathrm{N}=49 \mathrm{HC}=19, \text { New }(\text { type } 2)=14 \\
\text { Known }(\text { type } 2)=16\end{array}$ & $\begin{array}{c}\text { NGTs to Known }=\downarrow \\
\text { Methanobrevibacter }\end{array}$ & {$[22]$} \\
\hline \multirow[t]{2}{*}{ Human IBD } & $\mathrm{N}=58, \mathrm{HC}=29, \mathrm{IBD}=29$ & IBD to HC: $\uparrow$ M. stadtmanae & [128] \\
\hline & $\mathrm{N}=108, \mathrm{HC}=47, \mathrm{IBD}=61$ & IBD to HC: $\downarrow$ M. smithii & [129] \\
\hline \multicolumn{4}{|c|}{ Animal } \\
\hline Human/ape study & $\begin{array}{l}\text { Humans }(\mathrm{N}=10) \text { Apes: } \\
\text { Pan troglodytes (chimpanzee }=14), \\
\text { Pan paniscus (bonobo = 18), } \\
\text { Gorilla gorilla (gorilla = 20), } \\
\text { and Pongo pygmaeus (orangutan }=8)\end{array}$ & $\begin{array}{l}\text { Taxa identified: } \text { M. smithii and } \\
\text { M. stadtmanae in all samples } \\
\text { (more in humans) }\end{array}$ & {$[24]$} \\
\hline Rabbit cecal archaea & $\mathrm{N}=40$ & $\begin{array}{c}\text { Taxa identified: Methanobrevibacter } \\
\text { and Methanosphaera spp. } \\
\text { in all samples }\end{array}$ & {$[130]$} \\
\hline
\end{tabular}

\section{Helminths}

Helminths are a type of multicellular parasitic intestinal worms found in various locations such as intestinal lumen, blood, or muscles of the host, and are usually referred to as macrobiome, and are known to be present in one-third of the global human population. Enteric helminths should be considered as a part of the gut microbiota as they co-reside in the gut with bacteria, viruses, and fungi [131]. Most of the helminth's lifecycle is completed in the host's intestine by disrupting the 
intestinal microbial ecosystem and imparting epithelial damage (Table 7). To control this damage, hosts promote the rapid expansion of intestinal epithelial cell numbers, mucus production, promotion of Th2 responses, and activation of T regulatory (Treg) cells to limit inflammation and increase wound healing capacity. Although most of these worms are considered parasitic, Allen et al. [132] suggested a symbiotic relation between helminths and host, whereby helminths are tolerated, and intestinal tissue damage is minimized. In a Malaysian population-based study, individuals with helminths had higher microbial diversity as compared to individuals without helminths $[16,133]$. Increasing evidence suggests that helminths also regulate mucosal inflammation [134,135]. Infection with helminths may lead to anti-inflammatory effects in the gut; specifically, in the case of IBD with Trichiuris suis, helminthic worms have ameliorated disease activities [136,137]. However, the exact mechanism of how helminths may protect the host from the development of IBD remains unknown. More studies on helminths and their relationship with host immune responses could lead to highly effective therapeutic strategies for human IBD, and other autoimmune disorders.

Table 7. Summary of significant study findings on the role of helminths in health and disease.

\begin{tabular}{|c|c|c|c|}
\hline Model Type & Study Details & Findings & Ref. \\
\hline $\begin{array}{l}\text { Rat model } \\
(2,4,6 \text { Trinitrobenzene } \\
\text { sulphonic acid (TNBS) } \\
\text { induced colitis model }\end{array}$ & $\begin{array}{c}\mathrm{N}=24: \mathrm{HC}=6, \text { Schistosoma } \\
\text { mansoni group }=6, \\
\text { TNBS group }=6 \text { and } \\
\text { S. mansoni }+ \text { TNBS group }=6\end{array}$ & $\begin{array}{c}\text { S. mansoni group: } \uparrow \text { IL-2, IL-4 } \\
\text { TNBS group: } \uparrow \text { IL- } \uparrow \uparrow \text { T helper } 1 \text { (Th1) } \\
\text { S. mansoni plus TNBS group: } \\
\uparrow \text { Th } 2 \downarrow \text { Th } 1 \text { ( } \downarrow \text { Inflammation) } \\
\text { Concurrent infection with } S \text {. mansoni } \\
\text { significantly attenuates TNBS induced } \\
\text { colitis in the rats. }\end{array}$ & [138] \\
\hline $\begin{array}{l}\text { Rhesus macaques with } \\
\text { idiopathic chronic diarrhea } \\
\text { (ICD) w/o T suis infection }\end{array}$ & $\begin{array}{c}\mathrm{N}=7, \mathrm{ICD}=5 \\
\mathrm{ICD} \text { with } T \text { suis }=5, \mathrm{HC}=2\end{array}$ & $\begin{array}{c}\text { ICD group }=\downarrow \text { Mucosal bacterial diversity, } \\
\downarrow \text { Th2 } \\
\text { ICD with } T \text { suis }=\uparrow \text { Mucosal bacterial } \\
\text { diversity (Cyanobacteria), } \uparrow \text { Th2 }\end{array}$ & [139] \\
\hline $\begin{array}{l}\text { Human (Tetanus toxoid (TT) } \\
\text { and } S \text { mansoni infection) }\end{array}$ & $\begin{array}{c}\mathrm{TT}+\text { S. mansoni }=11 \\
\mathrm{HC}=5\end{array}$ & $\begin{array}{c}\text { TT }+ \text { S. mansoni group: } \downarrow \text { Interferon gamma } \\
\text { (IFN- }-\uparrow \text {, Th } 2 \\
\text { HC: } \uparrow \text { IFN- } \downarrow \downarrow \text { Th1 }\end{array}$ & [140] \\
\hline $\begin{array}{l}\text { Human } \\
\text { (helminthic ova in the } \\
\text { treatment of active IBD) }\end{array}$ & $\begin{array}{c}\mathrm{N}=4(\mathrm{IBD}), 2500 \text { live } \\
\text { Trichuris suis eggs/12 } \\
\text { weeks/subject }\end{array}$ & $\begin{array}{c}\text { IBD: } \uparrow \text { Inflammation: } \uparrow \text { Th1 } \\
\text { T. suis treated: } \downarrow \text { Inflammation: } \uparrow \text { Th2 and } \\
\downarrow \text { Th1 }\end{array}$ & [141] \\
\hline $\begin{array}{l}\text { Human (RCT T suis therapy } \\
\text { for ulcerative colitis (UC)) }\end{array}$ & $\begin{array}{c}\mathrm{N}=54, \text { Therapy group }=30, \\
\mathrm{HC}=24\end{array}$ & $\begin{array}{c}\text { Therapy group }=\downarrow \text { UC disease activity } \\
\text { index (DAI) }\end{array}$ & [137] \\
\hline $\begin{array}{l}\text { Human (RCT T suis therapy } \\
\text { for Crohn's disease (CD)) }\end{array}$ & $\begin{array}{c}\mathrm{N}=36, \text { Treated group }=27 \\
\mathrm{HC}=9\end{array}$ & T. suis therapy was well tolerated & [142] \\
\hline $\begin{array}{l}\text { Human (Necator americanus } \\
\text { therapy for CD) }\end{array}$ & $\mathrm{N}=18$, (inoculation) & $\begin{array}{l}\text { CD: } \uparrow \text { DAI } \\
\text { N. americanus treated: } \downarrow \text { CD (DAI) }\end{array}$ & [143] \\
\hline $\begin{array}{l}\text { Human ( } T \text { suis therapy } \\
\text { multiple sclerosis) }\end{array}$ & $\mathrm{N}=5$ & $\begin{array}{l}\text { Multiple sclerosis: } \uparrow \text { Inflammation } \\
\text { T. suis treated: } \uparrow \text { IL-4, } \uparrow \text { IL-10 } \\
\quad(\downarrow \text { Inflammation }=\uparrow \text { Th } 2 ?)\end{array}$ & [144] \\
\hline
\end{tabular}

\section{Cross-Kingdom Interactions}

Advances in 'omics' technologies have enabled researchers to better describe host-microbiome and microbiome-microbiome interactions, including the insight that different strains and species of microbes typically compete with each other for limited space and nutrients [145]. Emerging research suggests that the gut microbial system is densely colonized, promoting intense niche competitions for adhesion sites and nutrients (their limitations), and cooperation within and between microbial species [146]. Microbial competition occurs during initial encounters and gradually numbers reduce by co-exclusion, or niche separation or through spatial separation, enabling the coexistence of diverse communities [145]. Like environmental ecosystems, the gut microbial community is dynamic and regulated by cross-kingdom interactions (Figure 2). These intricate microbe-microbe 
and microbe-host-microbe interactions enable one microbial species to influence another and induce host response. Determining the role of the host in regulating these interactions and maintenance of homeostasis is vital to understanding species-level interactions in the gut.

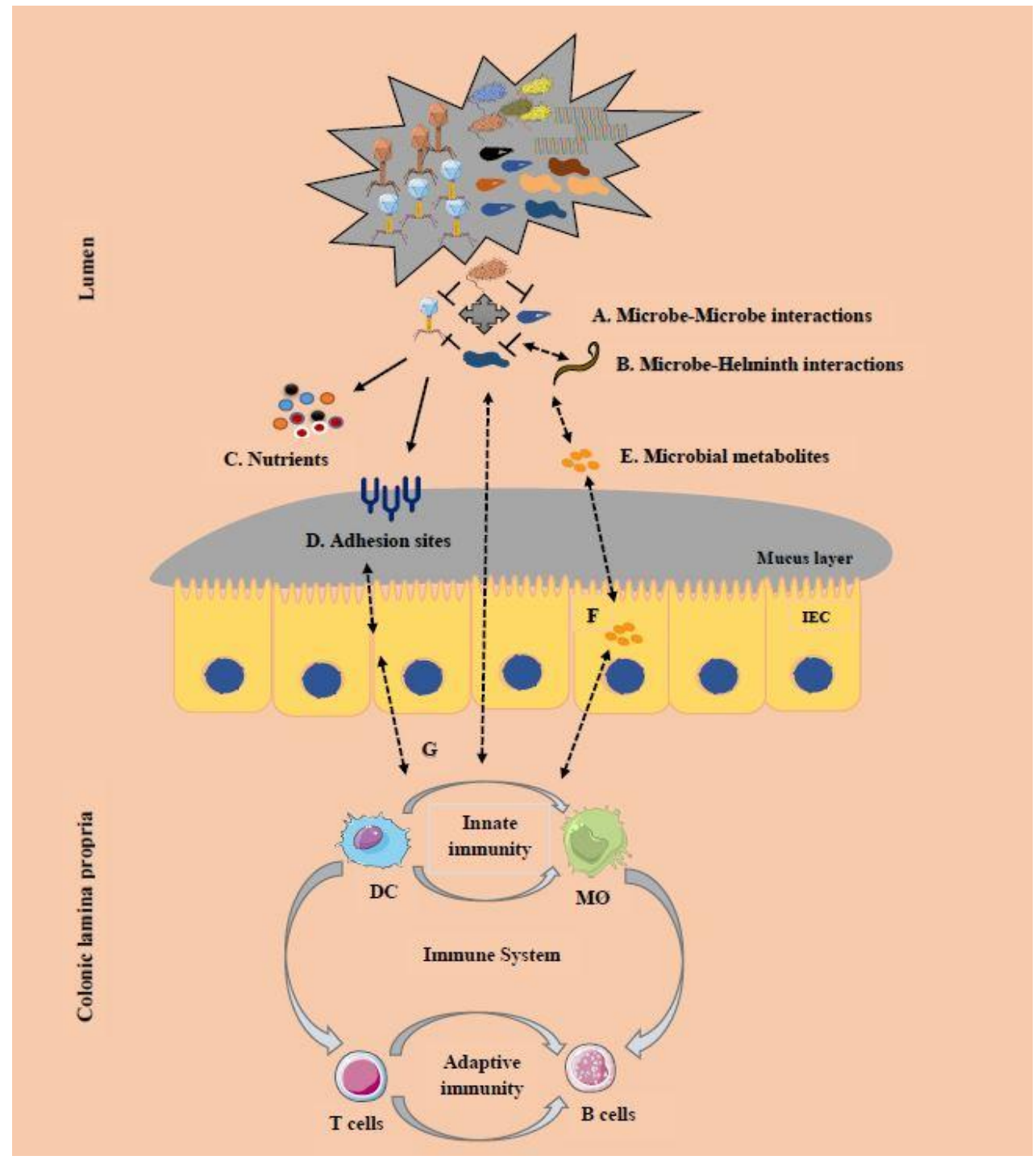

Figure 2. The microbial cross-kingdom interactions between members of microbiome. All the microbes in the gut interact with each other; Microbes interact with each other (A), with helminths (B) and their hosts, establishing trophic relationship (either symbiotic or parasitic). These interactions are categorized as competition or cooperation for survival, nutrients (C) and adhesion sites (D) on the mucosa. Most of these microbes produce specific metabolites (Short chain fatty acids) (E) and supply energy to intestinal epithelial cells (IEC), influencing the immune system (F-G), and overall homeostasis. DC = Dendritic cells; Mo = Macrophages.

It is clear that interdependence between bacteriome, virome, and mycobiome exist and any imbalance in the gut microbial composition can impact overall human health $[1,136]$. For example, the phage can lyse commensal or pathogenic bacteria and drive bacterial evolution in the gut, molding the gut bacteriome [36]. In turn, the bacteriome inhibits pathogen colonization via competition, produces secondary metabolites, energizes host intestinal epithelium and enhances immune responses by host-microbe cross talk. For example, metabolites produced by bacteria can inhibit $C$. albicans colonization and translocation across the intestinal barrier [20]. Moreover, the efficacy of FMT was 
reduced due to the presence of $C$. albicans in donor stool, suggesting a strong relationship between fungal dysbiosis and FMT outcome [147].

Most of the studies on the microbiome suggest common themes between bacteriome, virome, mycobiome, and host genetics; however, there is no study indicating their direct relationships. Multiple factors determine the effect of the microbiome on homeostasis. Until recently, most of the studies have characterized interactions between bacteria and the host, while the relationships involving virome and mycobiome have received less attention. A few studies reported that interactions between components of microbiome and host could modulate the infectivity of viruses, such as the interaction between bacteria, poliovirus, and reovirus [10]. Bacteria can enable viral replication and cellular binding, facilitating chronic infections [37], or can also negatively affect viral infections. Most studies utilizing lactic acid probiotic bacteria such as Lactobacillus have efficiently blocked virus infections caused by rotavirus [148]. Conversely, the introduction of fungi can alter the composition of local, downstream, and upstream bacterial microbiota, while bacterial microbiota and the intestinal epithelium influence the ability of fungi to colonize the gut [13]. The commensal mycobiome-associated metabolites and products can also influence immune homeostasis, while helminths have immuno-regulatory effects evolved from host-parasite interactions [96]. Together, the above findings suggest that each member of the microbiome can individually affect the host immune system via basal stimulation (Table 8).

Table 8. The immune responses associated with different members of the microbiome $([1,149,150])$.

\begin{tabular}{|c|c|c|c|c|}
\hline Microbial Constituent & Response Type & $\begin{array}{c}\text { Immune } \\
\text { Cells/Expressions }\end{array}$ & Cytokines & Initiation \\
\hline $\begin{array}{l}\text { Bacteria (intracellular): } \\
\text { Systemic commensals, } \\
\text { Proteobacteria, pathogens }\end{array}$ & $\begin{array}{l}\text { Inflammatory response } \\
\text { (IR) } 1\end{array}$ & T helper 1 (Th 1) cells & $\begin{array}{l}\text { Interferon gamma } \\
(\text { IFN-r), Tumor necrosis } \\
\text { factor (TNF- } \alpha)\end{array}$ & \multirow{2}{*}{$\begin{array}{l}\text { Microbe-associated } \\
\text { molecular patterns } \\
\text { (Pro-inflammatory) }\end{array}$} \\
\hline Virus & IR 1 & CD4, CD8 T cells & IFN- $\alpha / \beta$, IFN- $\lambda$ & \\
\hline $\begin{array}{c}\text { Segmented filamentous } \\
\text { bacteria (extracellular), } \\
\text { Fungi }\end{array}$ & IR 2 & Th 17 cells & $\begin{array}{l}\text { Interleukins (IL) 17A, } \\
\text { IL-22 }\end{array}$ & Mucosal epithelial cells \\
\hline Helminths & IR 2 & Th 2 cells & IFN-r & GATA 3 \\
\hline $\begin{array}{c}\text { Archaea } \\
\text { ((Methanomassiliicoccus } \\
\text { luminyensis, Methanosphaera } \\
\text { stadtmanae and M. smithii)) }\end{array}$ & $\begin{array}{l}\text { Inflammatory/regulatory } \\
\text { response }\end{array}$ & T cells- CD86, CD197 & $\begin{array}{c}\text { Monocyte-derived } \\
\text { dendritic cells (MODC), } \\
\text { type } 1 \text { IFN }\end{array}$ & Mucosal epithelial cells \\
\hline $\begin{array}{l}\text { Clostridia, Bacteroides fragilis, } \\
\text { archaea and helminths }\end{array}$ & Regulatory response & $\begin{array}{l}\text { T regulatory cells } \\
\text { (Foxp3 + Tregs) }\end{array}$ & $\begin{array}{l}\text { IL-10, Transforming } \\
\text { growth factor beta } \\
(\text { TGF- } \beta)\end{array}$ & Resolution of IR 1, 2 \\
\hline
\end{tabular}

Host immune responses are determined based on the characteristics of an individual member of the microbiome and its location (intra or extracellular) [149]. Bacteria, viruses, and fungi activate the innate part of the immune system via macrophages, which in turn actuate the adaptive immune system by employing T cells (pro-inflammatory) and their subsets such as T helper (Th) 1 and Th17 cells, respectively [150-152]. Similarly, helminths can activate macrophages and Th2 cells, leading to worm expulsion and inflammation. Excessive pro-inflammatory responses can cause damage to the host and thus are regulated by initiation tolerogenic regulatory responses via Treg cells [132] which reduce inflammation (Figure 3). Thus, the immunomodulatory effect of the microbiome promotes microbiome-immune tolerance and immune homeostasis. However, imbalance in the commensal microbial composition may play an important role in the development of autoimmune and chronic inflammatory responses. Trans-kingdom interplay, therefore, adds a layer of complexity in terms of host-microbial and immune homeostasis. Apart from bacteria, more definitively elucidating the roles of human gut virome, mycobiome, and helminths may have the potential to augment detection of disorders and act as disease markers. New developments in metagenomics, enrichment cultures, 
and bioinformatics tools are urgently required to improve our ability to define and characterize these biomes.

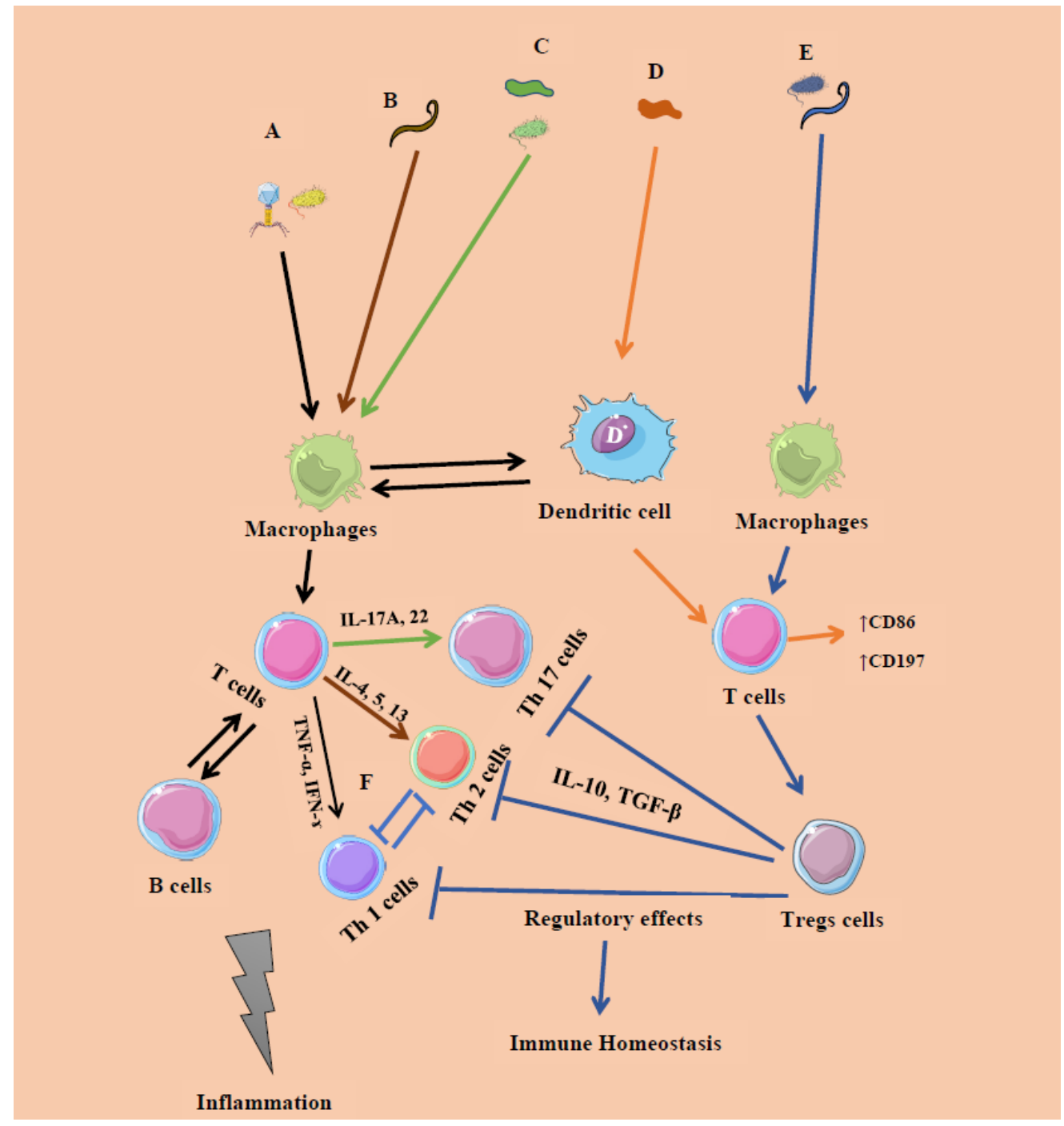

Figure 3. The known microbe-immune interactions in inflammation and homeostasis. A. Certain members of bacteria (intracellular, systemic commensals, Proteobacteria, and opportunist pathogens) and viruses induce inflammatory responses (IR 1) by promoting $\mathrm{T}$ cells and their subsets $\mathrm{T}$ helper 1 cells (Th 1) releasing pro-inflammatory cytokines such as interferon-gamma (IFN- $\gamma$ ), tumor necrosis factor-alpha (TNF- $\alpha$ ), etc., initiated by microbe-associated molecular patterns (Black arrow). B-C. Segmented filamentous bacteria (extracellular), member of Fungi, and helminths (GATA 3) induce inflammatory responses initiated at the mucosal sites, which promote the expansion of $\mathrm{T}$ cells expressing Th 17 and Th 2 cells releasing Interleukins (IL) 17A, IL-22, and IFN- $\gamma$, respectively (Brown and green). D. Certain members of Archaea (Methanomassiliicoccus luminyensis, Methanosphaera stadtmanae and M. smithii) promote surface markers CD86, CD197 expressed on T cells releasing Monocyte-derived dendritic cells (MODC), type 1 IFN (Orange). All the factors involving A-D may lead to tissue damage and ultimately inflammation. E-F. Certain members of Clostridia, Bacteroides fragilis, archaea, and helminths induce regulatory responses by promoting Foxp3-expressing T regulatory (Tregs) cells, limiting the activation of Th1, Th2, and Th17 cells (Blue). This regulation and tolerance promote homeostasis. 


\section{Modulation of the Microbiome and Related Concerns}

To manipulate the microbiota, one should account for all the members of the gut microbial community; to that end, diet is considered a vital factor to positively modulate the gut microbiome. Different diets, such as LFD and HFD, have varied effects on each microbial community of the gut. For instance, Bacteroides and Prevotella genera were found to correlate with different diets inversely. Abundance of Bacteroides was associated with high fats, amino acids, and choline consumption, whereas Prevotella is correlated with carbohydrate consumption [153]. Additionally, the phage community of the gut is significantly altered by diet based upon pre-existing populations, indicating that individuals with the same diet may have similar, but not identical, viromes [50]. Similar trends were observed in both mycobiome and archaeome. Recent and high consumption of carbohydrates is directly linked to abundance of Candida, whereas a long term patterns of carbohydrates consumption is linked to profusion of Methobrevibacter spp. [100].

A growing body of evidence demonstrates the use of probiotics, prebiotics, synbiotics (preand probiotics together), FMT, and recently FVT, to modulate the microbiome [1-3]. Although these therapies produced promising outcomes in a few clinical and experimental models, most of them have not been consistent and may not provide consistent clinical benefits. For example, probiotics (single or multi-strained) are considered natural, safe, and beneficial modulators of the gut microbial composition, but their efficacy is strain- and dose-dependent and not all probiotics function against all disorders and diseases [154]. Fundamentally, to confer health benefits a probiotic needs to survive the acidic gastric digestion, other digestive enzymes, reach the intestine and colonize on the intestinal epithelium in good numbers [114]. In most of the probiotic trials, the vehicles for probiotic intake used are yoghurt, biscuits, bars, and capsules, per oral, which is not consistent across the studies and can potentially confound the outcomes [155]. While the exact probiotic mechanism is still unknown, the route of administration and dosage form may influence colonization. The colonization of probiotic strains is also dependent on competition or cooperation (microbe-microbe interactions) with the resident microbiota. Recently, several commercially available probiotics are increasingly multi-strain rather than a single strain [155], but how these multi-strains work and interact with each other to confer health benefits is still unknown. Specific probiotic strains and their combinations need to be further investigated to deploy them to their full potential.

Synbiotics, combinations of pro- and prebiotics, are also arbitrarily chosen in many studies [156]. Sometimes the selected probiotic may not be able to even ferment the selected prebiotic strains $[2,156]$. The components of synbiotics are rarely tested individually in clinical or pre-clinical studies. Similarly, FMT is currently being explored for virome and mycobiome in the donor fecal samples and but also has not undergone rigorous component-based testing.

\section{Conclusions}

It is imperative to understand that gut microbiome/macrobiome is not limited to bacteria but also viruses, fungi, and helminths. All these microbes interacting with each other, and with the host, in combination or alone, influence the health of the host. Advances in NGS technologies enable us to study the whole microbiome in an integrative way by exploring the taxonomic profiles and functional attributes of the various microbial communities. Considerable further study will be required to understand the development and regulation of gut microbial communities and the factors mediating the balance between long-term stability and dynamic response to the environment.

Supplementary Materials: The following are available online at http://www.mdpi.com/2076-2607/8/4/483/s1, Table S1: Number of studies published in Web of Science and PubMed databases related to gut microbiome, gut virome, gut mycobiome, gut archaeome and helminths.

Author Contributions: Conceptualization, R.V..; Methodology, R.V.; Writing-Original Draft Preparation, R.V.; Writing-Review \& Editing, K.K., R.E., M.C., and E.M.S. All authors have read and agreed to the published version of the manuscript.

Funding: No funding was involved.

Conflicts of Interest: Authors declare no conflict of interest. 


\section{References}

1. Vemuri, R.; Gundamaraju, R.; Shastri, M.D.; Shukla, S.D.; Kalpurath, K.; Ball, M.; Tristram, S.; Shankar, E.M.; Ahuja, K.D.; Eri, R. Gut Microbial Changes, Interactions, and Their Implications on Human Lifecycle: An Ageing Perspective. BioMed Res. Int. 2018, 2018, 1-13. [CrossRef] [PubMed]

2. Vemuri, R.; Gundamaraju, R.; Eri, R. Role of lactic acid probiotic bacteria in IBD. Curr. Pharm. Des. $2017,23,1$. [CrossRef] [PubMed]

3. Vemuri, R.; Sylvia, K.; Klein, S.L.; Forster, S.C.; Plebanski, M.; Eri, R.; Flanagan, K.L. The microgenderome revealed: Sex differences in bidirectional interactions between the microbiota, hormones, immunity and disease susceptibility. Semin. Immunopathol. 2018, 41, 265-275. [CrossRef] [PubMed]

4. Gilbert, J.A.; Blaser, M.J.; Caporaso, J.G.; Jansson, J.K.; Lynch, S.V.; Knight, R. Current understanding of the human microbiome. Nat. Med. 2018, 24, 392-400. [CrossRef]

5. Yatsunenko, T.; Rey, F.E.; Manary, M.J.; Trehan, I.; Dominguez-Bello, M.G.; Contreras, M.; Magris, M.; Hidalgo, G.; Baldassano, R.N.; Anokhin, A.P.; et al. Human gut microbiome viewed across age and geography. Nature 2012, 486, 222-227. [CrossRef] [PubMed]

6. Zuo, T.; Kamm, M.A.; Colombel, J.-F.; Ng, S.C. Urbanization and the gut microbiota in health and inflammatory bowel disease. Nat. Rev. Gastroenterol. Hepatol. 2018, 15, 440-452. [CrossRef]

7. Hugerth, L.W.; Seifert, M.; Pennhag, A.A.L.; Du, J.; Hamsten, M.C.; Schuppe-Koistinen, I.; Engstrand, L. A comprehensive automated pipeline for human microbiome sampling, 16S rRNA gene sequencing and bioinformatics processing. BioRxiv 2018, 286526. [CrossRef]

8. Knight, R.; Vrbanac, A.; Taylor, B.C.; Aksenov, A.; Callewaert, C.; Debelius, J.; González, A.; Kosciolek, T.; McCall, L.-I.; McDonald, D.; et al. Best practices for analysing microbiomes. Nat. Rev. Genet. 2018, 16, 410-422. [CrossRef]

9. Stefanaki, C.; Peppa, M.; Mastorakos, G.; Chrousos, G.P. Examining the gut bacteriome, virome, and mycobiome in glucose metabolism disorders: Are we on the right track? Metabolism 2017, 73, 52-66. [CrossRef]

10. Mukhopadhya, I.; Segal, J.P.; Carding, S.R.; Hart, A.L.; Hold, G.L. The gut virome: The 'missing link' between gut bacteria and host immunity? Ther. Adv. Gastroenterol. 2019, 12. [CrossRef]

11. Forbes, J.D.; Bernstein, C.N.; Tremlett, H.; van Domselaar, G.; Knox, N. A Fungal World: Could the Gut Mycobiome Be Involved in Neurological Disease? Front. Microbiol. 2019, 9, 3249. [CrossRef]

12. Yutin, N.; Makarova, K.S.; Gussow, A.B.; Krupovic, M.; Segall, A.; Edwards, R.A.; Koonin, E.V. Discovery of an expansive bacteriophage family that includes the most abundant viruses from the human gut. Nat. Microbiol. 2017, 3, 38-46. [CrossRef] [PubMed]

13. Witherden, E.; Moyes, D.L. Mycobiome and Gut Inflammation. In Immunity and Inflammation in Health and Disease; Elsevier: Amsterdam, The Netherlands, 2018; pp. 271-280.

14. Gaci, N.; Borrel, G.; Tottey, W.; O’Toole, P.W.; Brugère, J.-F. Archaea and the human gut: New beginning of an old story. World J. Gastroenterol. 2014, 20, 16062-16078. [CrossRef] [PubMed]

15. Giacomin, P.; Agha, Z.; Loukas, A. Helminths and Intestinal Flora Team Up to Improve Gut Health. Trends Parasitol. 2016, 32, 664-666. [CrossRef] [PubMed]

16. Weinstock, J.V.; Elliott, D. Helminths and the IBD hygiene hypothesis. Inflamm. Bowel Dis. 2009, 15, 128-133. [CrossRef] [PubMed]

17. Moreno-Gallego, J.L.; Chou, S.-P.; Di Rienzi, S.C.; Goodrich, J.K.; Spector, T.D.; Bell, J.T.; Youngblut, N.D.; Hewson, I.; Reyes, A.; Ley, R.E. Virome Diversity Correlates with Intestinal Microbiome Diversity in Adult Monozygotic Twins. Cell Host Microbe 2019, 25, 261-272. [CrossRef] [PubMed]

18. Shkoporov, A.; Clooney, A.G.; Sutton, T.D.; Ryan, F.J.; Daly, K.M.; Nolan, J.A.; McDonnell, S.A.; Khokhlova, E.V.; Draper, L.A.; Forde, A.; et al. The Human Gut Virome Is Highly Diverse, Stable, and Individual Specific. Cell Host Microbe 2019, 26, 527-541. [CrossRef]

19. Reyes, A.; Haynes, M.; Hanson, N.; Angly, F.E.; Heath, A.C.; Rohwer, F.; Gordon, J.I. Viruses in the faecal microbiota of monozygotic twins and their mothers. Nature 2010, 466, 334-338. [CrossRef]

20. Nash, A.K.; Auchtung, T.; Wong, M.C.; Smith, D.; Gesell, J.; Ross, M.; Stewart, C.J.; Metcalf, G.A.; Muzny, D.; Gibbs, R.A.; et al. The gut mycobiome of the Human Microbiome Project healthy cohort. Microbiome 2017, 5, 153. [CrossRef] 
21. Motooka, D.; Fujimoto, K.; Tanaka, R.; Yaguchi, T.; Gotoh, K.; Maeda, Y.; Furuta, Y.; Kurakawa, T.; Goto, N.; Yasunaga, T.; et al. Fungal ITS1 Deep-Sequencing Strategies to Reconstruct the Composition of a 26-Species Community and Evaluation of the Gut Mycobiota of Healthy Japanese Individuals. Front. Microbiol. 2017, 8, 238. [CrossRef]

22. Bhute, S.; Suryavanshi, M.V.; Joshi, S.M.; Yajnik, C.S.; Shouche, Y.S.; Ghaskadbi, S.S. Gut Microbial Diversity Assessment of Indian Type-2-Diabetics Reveals Alterations in Eubacteria, Archaea, and Eukaryotes. Front. Microbiol. 2017, 8, 399. [CrossRef] [PubMed]

23. Eckburg, P.B.; Bik, E.M.; Bernstein, C.N.; Purdom, E.; Dethlefsen, L.; Sargent, M.; Gill, S.R.; Nelson, K.E.; Relman, D.A. Diversity of the Human Intestinal Microbial Flora. Science 2005, 308, 1635-1638. [CrossRef] [PubMed]

24. Raymann, K.; Moeller, A.H.; Goodman, A.L.; Ochman, H. Unexplored Archaeal Diversity in the Great Ape Gut Microbiome. mSphere 2017, 2. [CrossRef] [PubMed]

25. Miller, S.; Chiu, C. Metagenomic Next-Generation Sequencing for Pathogen Detection and Identification. In Advanced Techniques in Diagnostic Microbiology; Springer Science and Business Media LLC: Berlin/Heidelberg, Germany, 2018; pp. 617-632.

26. Roux, S.; Tournayre, J.; Mahul, A.; Debroas, D.; Enault, F. Metavir 2: New tools for viral metagenome comparison and assembled virome analysis. BMC Bioinform. 2014, 15, 76. [CrossRef] [PubMed]

27. Wommack, K.E.; Bhavsar, J.; Polson, S.W.; Chen, J.; Dumas, M.; Srinivasiah, S.; Furman, M.; Jamindar, S.; Nasko, D.J. VIROME: A standard operating procedure for analysis of viral metagenome sequences. Stand. Genom. Sci. 2012, 6, 427-439. [CrossRef] [PubMed]

28. Rampelli, S.; Soverini, M.; Turroni, S.; Quercia, S.; Biagi, E.; Brigidi, P.; Candela, M. ViromeScan: A new tool for metagenomic viral community profiling. BMC Genom. 2016, 17, 165. [CrossRef]

29. Angly, F.; Rodriguez-Brito, B.; Bangor, D.; McNairnie, P.; Breitbart, M.; Salamon, P.; Felts, B.; Nulton, J.; Mahaffy, J.; Rohwer, F. PHACCS, an online tool for estimating the structure and diversity of uncultured viral communities using metagenomic information. BMC Bioinform. 2005, 6, 41. [CrossRef]

30. Leplae, R.; Lima-Mendez, G.; Toussaint, A. ACLAME: A CLAssification of Mobile genetic Elements, update 2010. Nucleic Acids Res. 2009, 38, D57-D61. [CrossRef]

31. Zhao, G.; Wu, G.; Lim, E.S.; Droit, L.; Krishnamurthy, S.R.; Barouch, D.H.; Virgin, H.W.; Wang, D. VirusSeeker, a computational pipeline for virus discovery and virome composition analysis. Virology 2017, 503, 21-30. [CrossRef]

32. Pal, R.R.; More, R.P.; Purohit, H.J. Bioinformatics Tools for Shotgun Metagenomic Data Analysis. In Soft Computing for Biological Systems; Springer Science and Business Media LLC: Berlin/Heidelberg, Germany, 2018; pp. 91-110.

33. Barrientos-Somarribas, M.; Messina, D.; Pou, C.; Lysholm, F.; Bjerkner, A.; Allander, T.; Andersson, B.; Sonnhammer, E. Discovering viral genomes in human metagenomic data by predicting unknown protein families. Sci. Rep. 2018, 8, 28. [CrossRef]

34. Du Toit, A. Nature Reviews Microbiology. Nat. Rev. Genet. 2019. [CrossRef]

35. Shkoporov, A.; Khokhlova, E.V.; Fitzgerald, C.B.; Stockdale, S.R.; Draper, L.A.; Ross, R.; Hill, C. $\Phi C r$ Ass001 represents the most abundant bacteriophage family in the human gut and infects Bacteroides intestinalis. Nat. Commun. 2018, 9, 4781. [CrossRef] [PubMed]

36. Moya, A.; Brocal, V.P. The Human Virome; Springer: New York, NY, USA, 2018.

37. Barr, J.J.; Auro, R.; Furlan, M.; Whiteson, K.; Erb, M.L.; Pogliano, J.; Stotland, A.; Wolkowicz, R.; Cutting, A.S.; Doran, K.S.; et al. Bacteriophage adhering to mucus provide a non-host-derived immunity. Proc. Natl. Acad. Sci. USA 2013, 110, 10771-10776. [CrossRef] [PubMed]

38. Abeles, S.R.; Pride, D.T. Molecular Bases and Role of Viruses in the Human Microbiome. J. Mol. Boil. 2014, 426, 3892-3906. [CrossRef] [PubMed]

39. Kim, M.-S.; Park, E.-J.; Roh, S.W.; Bae, J.-W. Diversity and Abundance of Single-Stranded DNA Viruses in Human Feces. Appl. Environ. Microbiol. 2011, 77, 8062-8070. [CrossRef] [PubMed]

40. Moreno-Gallego, J.L.; Chou, S.-P.; Di Rienzi, S.; Goodrich, J.K.; Spector, T.; Bell, J.T.; Youngblut, N.; Hewson, I.; Reyes, A.; Ley, R.E. The virome in adult monozygotic twins with concordant or discordant gut microbiomes. bioRxiv 2019. [CrossRef]

41. Breitbart, M.; Haynes, M.; Kelley, S.; Angly, F.; Edwards, R.A.; Felts, B.; Mahaffy, J.M.; Mueller, J.; Nulton, J.; Rayhawk, S.; et al. Viral diversity and dynamics in an infant gut. Res Microbiol 2008, 159, 367-373. [CrossRef] 
42. Kolde, R.; Franzosa, E.A.; Rahnavard, G.; Hall, A.B.; Vlamakis, H.; Stevens, C.; Daly, M.J.; Xavier, R.J.; Huttenhower, C. Host genetic variation and its microbiome interactions within the Human Microbiome Project. Genome Med. 2018, 10, 6. [CrossRef]

43. Lim, E.S.; Zhou, Y.; Zhao, G.; Bauer, I.K.; Droit, L.; Ndao, I.M.; Warner, B.B.; Tarr, P.I.; Wang, D.; Holtz, L.R. Early life dynamics of the human gut virome and bacterial microbiome in infants. Nat. Med. 2015, 21, 1228-1234. [CrossRef]

44. Minot, S.; Bryson, A.; Chehoud, C.; Wu, G.D.; Lewis, J.D.; Bushman, F.D. Rapid evolution of the human gut virome. Proc. Natl. Acad. Sci. USA 2013, 110, 12450-12455. [CrossRef]

45. Reyes, A.; Blanton, L.V.; Cao, S.; Zhao, G.; Manary, M.; Trehan, I.; Smith, M.I.; Wang, D.; Virgin, H.W.; Rohwer, F.; et al. Gut DNA viromes of Malawian twins discordant for severe acute malnutrition. Proc. Natl. Acad. Sci. USA 2015, 112, 11941-11946. [CrossRef] [PubMed]

46. Maya-Lucas, O.; Murugesan, S.; Nirmalkar, K.; Alcaraz, L.D.; Hoyo-Vadillo, C.; Pizano-Zárate, M.L.; García-Mena, J.J.A. The gut microbiome of Mexican children affected by obesity. Anaerobe 2019, 55, 11-23. [CrossRef] [PubMed]

47. Breitbart, M.; Hewson, I.; Felts, B.; Mahaffy, J.M.; Nulton, J.; Salamon, P.; Rohwer, F. Metagenomic analyses of an uncultured viral community from human feces. J. Bacteriol. 2003, 185, 6220-6223. [CrossRef] [PubMed]

48. Zhang, T.; Breitbart, M.; Lee, W.H.; Run, J.-Q.; Wei, C.L.; Soh, S.W.L.; Hibberd, M.L.; Liu, E.T.; Rohwer, F.; Ruan, Y. RNA viral community in human feces: Prevalence of plant pathogenic viruses. PLoS Biol. 2005, 4, e3. [CrossRef]

49. Stockdale, S.R.; Ryan, F.J.; McCann, A.; Dalmasso, M.; Ross, P.R.; Hill, C. Viral Dark Matter in the Gut Virome of Elderly Humans. Preprints 2018. [CrossRef]

50. Minot, S.; Sinha, R.; Chen, J.; Li, H.; Keilbaugh, S.A.; Wu, G.D.; Lewis, J.D.; Bushman, F.D. The human gut virome: Inter-individual variation and dynamic response to diet. Genome Res. 2011, 21, 1616-1625. [CrossRef]

51. Zuo, T.; Lu, X.J.; Zhang, Y.; Cheung, C.P.; Lam, S.; Zhang, F.; Tang, W.; Ching, J.Y.L.; Zhao, R.; Chan, P.K.S.; et al. Gut mucosal virome alterations in ulcerative colitis. Gut 2019. [CrossRef]

52. Norman, J.M.; Handley, S.A.; Baldridge, M.T.; Droit, L.; Liu, C.Y.; Keller, B.C.; Kambal, A.; Monaco, C.L.; Zhao, G.; Fleshner, P.J.C. Disease-specific alterations in the enteric virome in inflammatory bowel disease. Cell 2015, 160, 447-460. [CrossRef]

53. Ma, Y.; You, X.; Mai, G.; Tokuyasu, T.; Liu, C.J.M. A human gut phage catalog correlates the gut phageome with type 2 diabetes. Microbiome 2018, 6, 24. [CrossRef]

54. Monaco, C.L.; Gootenberg, D.B.; Zhao, G.; Handley, S.A.; Ghebremichael, M.S.; Lim, E.S.; Lankowski, A.; Baldridge, M.T.; Wilen, C.B.; Flagg, M.J.; et al. Altered virome and bacterial microbiome in human immunodeficiency virus-associated acquired immunodeficiency syndrome. Cell Host Microbe 2016, 19, 311-322. [CrossRef]

55. D'arc, M.; Furtado, C.; Siqueira, J.D.; Seuánez, H.N.; Ayouba, A.; Peeters, M.; Soares, M.A. Assessment of the gorilla gut virome in association with natural simian immunodeficiency virus infection. Retrovirology 2018, 15, 19. [CrossRef] [PubMed]

56. Tan, Z.; Yu, H.; Xu, L.; Zhao, Z.; Zhang, P.; Qu, Y.; He, B.; Tu, C. Virome profiling of rodents in Xinjiang Uygur Autonomous Region, China: Isolation and characterization of a new strain of Wenzhou virus. Virology 2019, 529, 122-134. [CrossRef]

57. Phan, T.G.; Kapusinszky, B.; Wang, C.; Rose, R.K.; Lipton, H.L.; Delwart, E.L. The fecal viral flora of wild rodents. PLoS Pathog. 2011, 7, e1002218. [CrossRef] [PubMed]

58. Hansen, T.A.; Mollerup, S.; Nguyen, N.P.; White, N.E.; Coghlan, M.; Alquezar-Planas, D.E.; Joshi, T.; Jensen, R.H.; Fridholm, H.; Kjartansdóttir, K.R.; et al. High diversity of picornaviruses in rats from different continents revealed by deep sequencing. Emerging Microbes Infections 2016, 5, 1-8. [CrossRef] [PubMed]

59. Williams, S.H.; Che, X.; Garcia, J.A.; Klena, J.D.; Lee, B.; Muller, D.; Ulrich, W.; Corrigan, R.M.; Nichol, S.; Jain, K.J.M. Viral diversity of house mice in New York City. Am. Soc. Microbiol. 2018, 9, e01354-17. [CrossRef]

60. Duerkop, B.A.; Kleiner, M.; Paez-Espino, D.; Zhu, W.; Bushnell, B.; Hassell, B.; Winter, S.E.; Kyrpides, N.C.; Hooper, L.V. Murine colitis reveals a disease-associated bacteriophage community. Nat. Microbil. 2018, 3, 1023. [CrossRef]

61. Seth, R.; Maqsood, R.; Mondal, A.; Bose, D.; Kimono, D.; Holland, L.; Janulewicz, P.A.; Klimas, N.; Horner, R.D.; Sullivan, K.; et al. Gut DNA Virome Diversity and Its Association with Host Bacteria Regulate Inflammatory Phenotype and Neuronal Immunotoxicity in Experimental Gulf War Illness. Viruses 2019, 11, 968. [CrossRef] 
62. Reyes, A.; Wu, M.; McNulty, N.P.; Rohwer, F.L.; Gordon, J.I. Gnotobiotic mouse model of phage-bacterial host dynamics in the human gut. Proc. Natl. Acad. Sci. USA 2013, 110, 20236-20241. [CrossRef]

63. Minot, S.S.; Wu, G.D.; Lewis, J.D.; Bushman, F.D. Conservation of Gene Cassettes among Diverse Viruses of the Human Gut. PLoS ONE 2012, 7, e42342. [CrossRef]

64. Finkbeiner, S.R.; Allred, A.F.; Tarr, P.I.; Klein, E.J.; Kirkwood, C.D.; Wang, D. Metagenomic Analysis of Human Diarrhea: Viral Detection and Discovery. PLOS Pathog. 2008, 4, e1000011. [CrossRef]

65. Ogilvie, L.; Jones, B.V. The human gut virome: A multifaceted majority. Front. Microbiol. 2015, 6, 918. [CrossRef] [PubMed]

66. Lopetuso, L.R.; Ianiro, G.; Scaldaferri, F.; Cammarota, G.; Gasbarrini, A. Gut Virome and Inflammatory Bowel Disease. Inflamm. Bowel Dis. 2016, 22, 1708-1712. [CrossRef] [PubMed]

67. Zhao, G.; Vatanen, T.; Droit, L.; Park, A.; Kostic, A.D.; Poon, T.W.; Vlamakis, H.; Siljander, H.; Härkönen, T.; Hämäläinen, A.-M.; et al. Intestinal virome changes precede autoimmunity in type I diabetes-susceptible children. Proc. Natl. Acad. Sci. USA 2017, 114, E6166-E6175. [CrossRef] [PubMed]

68. Waller, A.S.; Yamada, T.; Kristensen, D.M.; Kultima, J.R.; Sunagawa, S.; Koonin, E.V.; Bork, P. Classification and quantification of bacteriophage taxa in human gut metagenomes. ISME J. 2014, 8, 1391-1402. [CrossRef] [PubMed]

69. Phan, T.G.; Da Costa, A.C.; Del Valle-Mendoza, J.; Bucardo-Rivera, F.; Nordgren, J.; O’Ryan, M.; Deng, X.; Delwart, E. The fecal virome of South and Central American children with diarrhea includes small circular DNA viral genomes of unknown origin. Arch. Virol. 2016, 161, 959-966. [CrossRef] [PubMed]

70. Smits, S.L.; Schapendonk, C.M.; Van Beek, J.; Vennema, H.; Schürch, A.C.; Schipper, D.; Bodewes, R.; Haagmans, B.L.; Osterhaus, A.D.M.E.; Koopmans, M. New Viruses in Idiopathic Human Diarrhea Cases, the Netherlands. Emerg. Infect. Dis. 2014, 20, 1218-1222. [CrossRef]

71. Park, A.; Zhao, G. Mining the Virome for Insights into Type 1 Diabetes. DNA Cell Boil. 2018, 37, 422-425. [CrossRef]

72. Chehoud, C.; Dryga, A.; Hwang, Y.; Nagy-Szakal, R.; Hollister, E.B.; Luna, R.A.; Versalovic, J.; Kellermayer, R.; Bushman, F.D. Transfer of Viral Communities between Human Individuals during Fecal Microbiota Transplantation. mBio 2016, 7, e00322-16. [CrossRef]

73. Zuo, T.; Wong, S.H.; Lam, K.; Lui, R.; Cheung, K.; Tang, W.; Ching, J.Y.L.; Chan, P.K.S.; Chan, M.; Wu, J.C.Y.; et al. Bacteriophage transfer during faecal microbiota transplantation inClostridium difficileinfection is associated with treatment outcome. Gut 2017, 67, 634-643. [CrossRef]

74. Draper, L.A.; Ryan, F.; Smith, M.K.; Jalanka, J.; Mattila, E.; Arkkila, P.A.; Ross, R.; Satokari, R.; Hill, C. Long-term colonisation with donor bacteriophages following successful faecal microbial transplantation. Microbiome 2018, 6, 220. [CrossRef]

75. Ott, S.J.; Waetzig, G.H.; Rehman, A.; Anderson, J.M.; Bharti, R.; Grasis, J.A.; Cassidy, L.; Tholey, A.; Fickenscher, H.; Seegert, D.; et al. Efficacy of Sterile Fecal Filtrate Transfer for Treating Patients With Clostridium difficile Infection. Gastroenterol. 2017, 152, 799-811. [CrossRef] [PubMed]

76. Bao, H.-D.; Pang, M.-D.; Olaniran, A.; Zhang, X.-H.; Zhang, H.; Zhou, Y.; Sun, L.-C.; Schmidt, S.; Wang, R. Alterations in the diversity and composition of mice gut microbiota by lytic or temperate gut phage treatment. Appl. Microbiol. Biotechnol. 2018, 102, 10219-10230. [CrossRef] [PubMed]

77. Lin, D.M.; Koskella, B.; Ritz, N.L.; Lin, D.; Carroll-Portillo, A.; Lin, H.C. Transplanting Fecal Virus-Like Particles Reduces High-Fat Diet-Induced Small Intestinal Bacterial Overgrowth in Mice. Front. Microbiol. 2019, 9, 348. [CrossRef] [PubMed]

78. Rasmussen, T.S.; Mentzel, C.M.J.; Kot, W.; Castro-Mejía, J.L.; Zuffa, S.; Swann, J.R.; Hansen, L.H.; Vogensen, F.K.; Hansen, A.K.; Nielsen, D.S. Faecal virome transplantation decreases symptoms of type 2 diabetes and obesity in a murine model. Gut 2020. [CrossRef]

79. Turnbaugh, P.J.; Ley, R.E.; Mahowald, M.A.; Magrini, V.; Mardis, E.R.; Gordon, J.I. An obesity-associated gut microbiome with increased capacity for energy harvest. Nature 2006, 444, 1027-1031. [CrossRef]

80. Hsu, B.B.; Gibson, T.E.; Yeliseyev, V.; Liu, Q.; Lyon, L.; Bry, L.; Silver, P.A.; Gerber, G.K. Dynamic Modulation of the Gut Microbiota and Metabolome by Bacteriophages in a Mouse Model. Cell Host Microbe 2019, 25, 803-814. [CrossRef]

81. Conceição-Neto, N.; Deboutte, W.; Dierckx, T.; Machiels, K.; Wang, J.; Yinda, K.C.; Maes, P.; Van Ranst, M.; Joossens, M.; Raes, J.; et al. Low eukaryotic viral richness is associated with faecal microbiota transplantation success in patients with UC. Gut 2017, 67, 1558-1559. [CrossRef] 
82. Jones, L.; Kumar, J.; Mistry, A.; Sankar Chittoor Mana, T.; Perry, G.; Reddy, V.P.; Obrenovich, M. The Transformative Possibilities of the Microbiota and Mycobiota for Health, Disease, Aging, and Technological Innovation. Biomedicines 2019, 7, 24. [CrossRef]

83. Tang, J.; Iliev, I.D.; Brown, J.; Underhill, D.M.; Funari, V.A. Mycobiome: Approaches to Analysis of Intestinal Fungi. J. Immunol. Methods 2015, 421, 112-121. [CrossRef]

84. Kõljalg, U.; Nilsson, R.H.; Abarenkov, K.; Tedersoo, L.; Taylor, A.F.S.; Bahram, M.; Bates, S.T.; Bruns, T.D.; Bengtsson-Palme, J.; Callaghan, T.M.; et al. Towards a unified paradigm for sequence-based identification of fungi. Mol. Ecol. 2013, 22, 5271-5277. [CrossRef]

85. Abarenkov, K.; Nilsson, R.H.; Larsson, K.-H.; Alexander, I.J.; Eberhardt, U.; Erland, S.; Høiland, K.; Kjøller, R.; Larsson, E.; Pennanen, T.; et al. The UNITE database for molecular identification of fungi - recent updates and future perspectives. New Phytol. 2010, 186, 281-285. [CrossRef] [PubMed]

86. Findley, K.; Oh, J.; Yang, J.; Conlan, S.; Deming, C.; Meyer, J.A.; Schoenfeld, D.; Nomicos, E.; Park, M.; NIH Intramural Sequencing Center Comparative Sequencing Program; et al. Topographic diversity of fungal and bacterial communities in human skin. Nature 2013, 498, 367-370. [CrossRef] [PubMed]

87. Santamaria, M.; Fosso, B.; Consiglio, A.; De Caro, G.; Grillo, G.; Licciulli, F.; Liuni, S.; Marzano, M.; Alonso-Alemany, D.; Valiente, G.; et al. Reference databases for taxonomic assignment in metagenomics. Briefings Bioinform. 2012, 13, 682-695. [CrossRef]

88. Koetschan, C.; Hackl, T.; Müller, T.; Wolf, M.; Förster, F.; Schultz, J. ITS2 Database IV: Interactive taxon sampling for internal transcribed spacer 2 based phylogenies. Mol. Phylogenetics Evol. 2012, 63, 585-588. [CrossRef]

89. Schoch, C.L.; Robbertse, B.; Robert, V.; Vu, D.; Cardinali, G.; Irinyi, L.; Meyer, W.; Nilsson, R.H.; Hughes, K.; Miller, A.N.; et al. Finding needles in haystacks: Linking scientific names, reference specimens and molecular data for Fungi. Database 2014. [CrossRef]

90. Irinyi, L.; Serena, C.; Garcia-Hermoso, D.; Arabatzis, M.; Desnos-Ollivier, M.; Vu, D.; Cardinali, G.; Arthur, I.; Normand, A.-C.; Giraldo, A.; et al. International Society of Human and Animal Mycology (ISHAM)-ITS reference DNA barcoding database-The quality controlled standard tool for routine identification of human and animal pathogenic fungi. Med Mycol. 2015, 53, 313-337. [CrossRef]

91. Pruesse, E.; Quast, C.; Knittel, K.; Fuchs, B.M.; Ludwig, W.; Peplies, J.; Glöckner, F.O. SILVA: A comprehensive online resource for quality checked and aligned ribosomal RNA sequence data compatible with ARB. Nucleic Acids Res. 2007, 35, 7188-7196. [CrossRef]

92. Standaert, A.; Sendid, B.; Joossens, M.; François, N.; Khoury, P.V.-E.; Branche, J.; Van Kruiningen, H.; Jouault, T.; Rutgeerts, P.; Gower, C.; et al. Candida albicans Colonization and ASCA in Familial Crohn's Disease. Am. J. Gastroenterol. 2009, 104, 1745-1753. [CrossRef] [PubMed]

93. Tamura, K.; Dudley, J.; Nei, M.; Kumar, S. MEGA4: Molecular Evolutionary Genetics Analysis (MEGA) Software Version 4.0. Mol. Boil. Evol. 2007, 24, 1596-1599. [CrossRef] [PubMed]

94. Qin, J.; Li, R.; Raes, J.; Arumugam, M.; Burgdorf, K.; Manichanh, C.; Nielsen, T.; Pons, N.; Levenez, F.; Yamada, T.; et al. A human gut microbial gene catalogue established by metagenomic sequencing. Nature 2010, 464, 59-65. [CrossRef] [PubMed]

95. Hallen-Adams, H.E.; Suhr, M.J. Fungi in the healthy human gastrointestinal tract. Virulence 2016, 8, 352-358. [CrossRef]

96. Wheeler, M.L.; Limon, J.J.; Bar, A.S.; Leal, C.A.; Gargus, M.; Tang, J.; Brown, J.; Funari, V.A.; Wang, H.L.; Crother, T.R.; et al. Immunological Consequences of Intestinal Fungal Dysbiosis. Cell Host Microbe 2016, 19, 865-873. [CrossRef] [PubMed]

97. Sokol, H.; Leducq, V.; Aschard, H.; Pham, H.-P.; Jegou, S.; Landman, C.; Cohen, D.; Liguori, G.; Bourrier, A.; Nion-Larmurier, I.; et al. Fungal microbiota dysbiosis in IBD. Gut 2016, 66, 1039-1048. [CrossRef]

98. Limon, J.J.; Skalski, J.; Underhill, D.M. Commensal Fungi in Health and Disease. Cell Host Microbe 2017, 22, 156-165. [CrossRef]

99. Lai, G.C.; Tan, T.G.; Pavelka, N. The mammalian mycobiome: A complex system in a dynamic relationship with the host. Wiley Interdiscip. Rev. Syst. Boil. Med. 2018, 11, e1438. [CrossRef] [PubMed]

100. Hoffmann, C.; Dollive, S.; Grunberg, S.; Chen, J.; Li, H.; Wu, G.D.; Lewis, J.D.; Bushman, F.D. Archaea and Fungi of the Human Gut Microbiome: Correlations with Diet and Bacterial Residents. PLoS ONE 2013, 8, e66019. [CrossRef] [PubMed]

101. Schei, K.; Avershina, E.; Øien, T.; Rudi, K.; Follestad, T.; Salamati, S.; Ødegård, R.A. Early gut mycobiota and mother-offspring transfer. Microbiome 2017, 5, 107. [CrossRef] [PubMed] 
102. Rosin, M.; Lee, A.; Boxen, K.; Duncan, A.; Rosendale, D.; Villas-Boas, S.; McKenzie, E.J. The New Zealand human gut mycobiome. In Proceedings of the Foodomics 2019 High Value Nutrition National Science Challenge, Auckland, New Zealand, 9-11 April 2019.

103. Ahmad, H.F.B.; Mejia, J.L.C.; Kot, W.; Bechshøft, R.L.; Reitelseder, S.; Holm, L.; Nielsen, D.S. The Gut Mycobiome of Elderly Danes. In Proceedings of the Danish Microbiological Society Annual Congress 2016, Comenhagen, Denmark, 14 November 2016.

104. Borges, F.M.; De Paula, T.O.; Sarmiento, M.R.A.; De Oliveira, M.G.; Pereira, M.L.M.; Toledo, I.V.; Nascimento, T.C.; Ferreira-Machado, A.B.; Silva, V.L.; Diniz, C.G. Fungal Diversity of Human Gut Microbiota Among Eutrophic, Overweight, and Obese Individuals Based on Aerobic Culture-Dependent Approach. Curr. Microbiol. 2018, 75, 726-735. [CrossRef]

105. Botschuijver, S.; Roeselers, G.; Levin, E.; Jonkers, D.M.; Welting, O.; Heinsbroek, S.E.M.; De Weerd, H.H.; Boekhout, T.; Fornai, M.; Masclee, A.A.; et al. Intestinal Fungal Dysbiosis Is Associated With Visceral Hypersensitivity in Patients With Irritable Bowel Syndrome and Rats. Gastroenterol. 2017, 153, 1026-1039. [CrossRef]

106. Li, J.; Li, L.; Jiang, H.; Yuan, L.; Zhang, L.; Ma, J.-E.; Zhang, X.; Cheng, M.; Chen, J. Fecal Bacteriome and Mycobiome in Bats with Diverse Diets in South China. Curr. Microbiol. 2018, 75, 1352-1361. [CrossRef]

107. Foster, M.L.; Dowd, S.E.; Stephenson, C.; Steiner, J.M.; Suchodolski, J.S. Characterization of the Fungal Microbiome (Mycobiome) in Fecal Samples from Dogs. Veter. Med. Int. 2013, 2013, 1-8. [CrossRef] [PubMed]

108. Aykut, B.; Pushalkar, S.; Chen, R.; Li, Q.; Abengozar, R.; Kim, J.I.; Shadaloey, S.A.; Wu, D.; Preiss, P.; Verma, N.; et al. The fungal mycobiome promotes pancreatic oncogenesis via activation of MBL. Nature 2019, 574, 264-267. [CrossRef] [PubMed]

109. Sun, B.; Huffman, M.A.; Li, J.-H. The Gut Microbiome of Tibetan Macaques: Composition, Influencing Factors and Function in Feeding Ecology. In The Evolution of Feathers; Springer Science and Business Media LLC: Berlin/Heilderbeg, Germany, 2019; pp. 207-222.

110. Lurie-Weinberger, M.N.; Gophna, U. Archaea in and on the Human Body: Health Implications and Future Directions. PLOS Pathog. 2015, 11, e1004833. [CrossRef] [PubMed]

111. Dridi, B.; Fardeau, M.-L.; Ollivier, B.; Raoult, D.; Drancourt, M. Methanomassiliicoccus luminyensis gen. nov., sp. nov., a methanogenic archaeon isolated from human faeces. Int. J. Syst. Evol. Microbiol. 2012, 62, 1902-1907. [CrossRef]

112. Dridi, B.; Henry, M.; El Khéchine, A.; Raoult, D.; Drancourt, M. High Prevalence of Methanobrevibacter smithii and Methanosphaera stadtmanae Detected in the Human Gut Using an Improved DNA Detection Protocol. PLoS ONE 2009, 4, e7063. [CrossRef] [PubMed]

113. Mihajlovski, A.; Doré, J.; Levenez, F.; Alric, M.; Brugère, J.-F. Molecular evaluation of the human gut methanogenic archaeal microbiota reveals an age-associated increase of the diversity. Environ. Microbiol. Rep. 2010, 2, 272-280. [CrossRef] [PubMed]

114. Vemuri, R.; Shinde, T.; Shastri, M.D.; Perera, A.P.; Tristram, S.; Martoni, C.J.; Gundamaraju, R.; Ahuja, K.D.K.; Ball, M.; Eri, R. A human origin strain Lactobacillus acidophilus DDS-1 exhibits superior in vitro probiotic efficacy in comparison to plant or dairy origin probiotics. Int. J. Med Sci. 2018, 15, 840-848. [CrossRef]

115. Goodrich, J.K.; Waters, J.L.; Poole, A.; Sutter, J.L.; Koren, O.; Blekhman, R.; Beaumont, M.; Van Treuren, W.; Knight, R.; Bell, J.T.; et al. Human Genetics Shape the Gut Microbiome. Cell 2014, 159, 789-799. [CrossRef]

116. Pimentel, M.; Lin, H.; Enayati, P.; Burg, B.V.D.; Lee, H.-R.; Chen, J.H.; Park, S.; Kong, Y.; Conklin, J. Methane, a gas produced by enteric bacteria, slows intestinal transit and augments small intestinal contractile activity. Am. J. Physiol. Liver Physiol. 2006, 290, G1089-G1095. [CrossRef]

117. Lurie-Weinberger, M.N.; Peeri, M.; Tuller, T.; Gophna, U. Extensive Inter-Domain Lateral Gene Transfer in the Evolution of the Human Commensal Methanosphaera stadtmanae. Front. Genet. 2012, 3, 182. [CrossRef]

118. Lurie-Weinberger, M.N.; Peeri, M.; Gophna, U. Contribution of lateral gene transfer to the gene repertoire of a gut-adapted methanogen. Genome 2012, 99, 52-58. [CrossRef] [PubMed]

119. Bang, C.; Weidenbach, K.; Gutsmann, T.; Heine, H.; Schmitz-Streit, R.A. The Intestinal Archaea Methanosphaera stadtmanae and Methanobrevibacter smithii Activate Human Dendritic Cells. PLoS ONE 2014, 9, e99411. [CrossRef] [PubMed]

120. Oxley, A.P.A.; Lanfranconi, M.P.; Würdemann, D.; Ott, S.; Stefánsson, K.; McGenity, T.J.; Timmis, K.N.; Nogales, B. Halophilic archaea in the human intestinal mucosa. Environ. Microbiol. 2010, 12, 2398-2410. [CrossRef] 
121. Wampach, L.; Heintz-Buschart, A.; Hogan, A.; Muller, E.; Narayanasamy, S.; Laczny, C.C.; Hugerth, L.W.; Bindl, L.; Bottu, J.; Andersson, A.F.; et al. Colonization and Succession within the Human Gut Microbiome by Archaea, Bacteria, and Microeukaryotes during the First Year of Life. Front. Microbiol. 2017, 8, 434. [CrossRef] [PubMed]

122. Mbakwa, C.A.; Penders, J.; Savelkoul, P.H.; Thijs, C.; Dagnelie, P.C.; Mommers, M.; Arts, I.C. Gut colonization with Methanobrevibacter smithii is associated with childhood weight development. Obesity 2015, 23, 2508-2516. [CrossRef] [PubMed]

123. Abell, G.C.; Conlon, M.A.; McOrist, A.L. Methanogenic archaea in adult human faecal samples are inversely related to butyrate concentration. Microb. Ecol. Heal. Dis. 2006, 18, 154-160.

124. Jalanka, J.; Salonen, A.; Nikkilä, J.; Immonen, O.; Kekkonen, R.; Lahti, L.; Palva, A.; De Vos, W.M. Intestinal Microbiota in Healthy Adults: Temporal Analysis Reveals Individual and Common Core and Relation to Intestinal Symptoms. PLOS ONE 2011, 6, e23035.

125. Falony, G.; Joossens, M.; Vieira-Silva, S.; Wang, J.; Darzi, Y.; Faust, K.; Kurilshikov, A.; Bonder, M.-J.; Valles-Colomer, M.; Vandeputte, D.; et al. Population-level analysis of gut microbiome variation. Science 2016, 352, 560-564. [CrossRef]

126. Dridi, B.; Henry, M.; Richet, H.; Raoult, D.; Drancourt, M.J.A. Age-related prevalence of M ethanomassiliicoccus luminyensis in the human gut microbiome. Apmis 2012, 120, 773-777. [CrossRef]

127. Borrel, G.; McCann, A.; Deane, J.; Neto, M.C.; Lynch, D.B.; Brugère, J.-F.; O’Toole, P.W. Genomics and metagenomics of trimethylamine-utilizing Archaea in the human gut microbiome. ISME J. 2017, 11, 2059-2074. [CrossRef]

128. Lecours, P.B.; Marsolais, D.; Cormier, Y.; Berberi, M.; Haché, C.; Bourdages, R.; Duchaine, C. Increased Prevalence of Methanosphaera stadtmanae in Inflammatory Bowel Diseases. PLoS ONE 2014, 9, e87734. [CrossRef]

129. Ghavami, S.B.; Rostami, E.; Sephay, A.A.; Shahrokh, S.; Balaii, H.; Aghdaei, H.A.; Zali, M.R. Alterations of the human gut Methanobrevibacter smithii as a biomarker for inflammatory bowel diseases. Microb. Pathog. 2018, 117, 285-289. [CrossRef]

130. Zhu, Y.; Sun, Y.; Wang, C.; Li, F. Impact of dietary fibre: Starch ratio in shaping caecal archaea revealed in rabbits. J. Anim. Physiol. Anim. Nutr. 2016, 101, 635-640. [CrossRef] [PubMed]

131. Weinstock, J.V.; Summers, R.; Elliott, D. Helminths and harmony. Gut 2004, 53, 7-9. [CrossRef] [PubMed]

132. Allen, J.E.; Maizels, R.M. Diversity and dialogue in immunity to helminths. Nat. Rev. Immunol. 2011, 11, 375-388. [CrossRef]

133. Weinstock, J.V.; Summers, R.W.; Elliott, D.; Qadir, K.; Urban, J.F.; Thompson, R. The possible link between de-worming and the emergence of immunological disease. J. Lab. Clin. Med. 2002, 139, 334-338. [CrossRef] [PubMed]

134. Giacomin, P.; Croese, J.; Krause, L.; Loukas, A.; Cantacessi, C. Suppression of inflammation by helminths: A role for the gut microbiota? Philos. Trans. R. Soc. B: Boil. Sci. 2015, 370, 20140296. [CrossRef] [PubMed]

135. Ramanan, D.; Bowcutt, R.; Lee, S.C.; Tang, M.S.; Kurtz, Z.D.; Ding, Y.; Honda, K.; Gause, W.C.; Blaser, M.J.; Bonneau, R.A.; et al. Helminth infection promotes colonization resistance via type 2 immunity. Science 2016, 352, 608-612. [CrossRef] [PubMed]

136. Helmby, H. Human helminth therapy to treat inflammatory disorders-Where do we stand? BMC Immunol. 2015, 16, 12. [CrossRef] [PubMed]

137. Summers, R.W.; Elliott, D.; Urban, J.F.; Thompson, R.A.; Weinstock, J.V. Trichuris suis therapy for active ulcerative colitis: A randomized controlled trial. Gastroenterol. 2005, 128, 825-832. [CrossRef]

138. Moreels, T.G.; Nieuwendijk, R.J.; De Man, J.G.; De Winter, B.Y.; Herman, A.G.; Van Marck, E.A.; Pelckmans, P.A. Concurrent infection with Schistosoma mansoni attenuates inflammation induced changes in colonic morphology, cytokine levels, and smooth muscle contractility of trinitrobenzene sulphonic acid induced colitis in rats. Gut 2004, 53, 99-107. [CrossRef] [PubMed]

139. Broadhurst, M.J.; Ardeshir, A.; Kanwar, B.; Mirpuri, J.; Gundra, U.M.; Leung, J.; Wiens, K.; Vujkovic-Cvijin, I.; Kim, C.C.; Yarovinsky, F.; et al. Therapeutic Helminth Infection of Macaques with Idiopathic Chronic Diarrhea Alters the Inflammatory Signature and Mucosal Microbiota of the Colon. PLOS Pathog. 2012, 8 , e1003000. [CrossRef] [PubMed]

140. Sabin, E.A.; Carvalho, E.M.; Araujo, M.I.; Pearce, E.J. Impairment of Tetanus Toxoid-Specific Thl-like Immune Responses in Humans Infected with Schistosoma mansoni. J. Infect. Dis. 1996, 173, 269-272. [CrossRef] [PubMed] 
141. Summers, R.W.; Elliott, D.E.; Qadir, K.; Urban, J.F., Jr.; Thompson, R.; Weinstock, J.V. Trichuris suis seems to be safe and possibly effective in the treatment of inflammatory bowel disease. Am. J. Gastoeneorol. 2003, 98, 2034. [CrossRef]

142. Sandborn, W.; Elliott, D.; Weinstock, J.; Summers, R.; Landry-Wheeler, A.; Silver, N.; Harnett, M.; Hanauer, S. Randomised clinical trial: The safety and tolerability of T richuris suis ova in patients with Crohn's disease. Aliment Pharnacol. Ther. 2013, 38, 255-263. [CrossRef]

143. Croese, J.; O'neil, J.; Masson, J.; Cooke, S.; Melrose, W.; Pritchard, D.; Speare, R. A proof of concept study establishing Necator americanus in Crohn's patients and reservoir donors. Gut 2006, 55, 136-137. [CrossRef]

144. Fleming, J.O.; Isaák, A.; Lee, J.E.; Luzzio, C.C.; Carrithers, M.D.; Cook, T.D.; Field, A.S.; Boland, J.; Fabry, Z. Probiotic helminth administration in relapsing—Remitting multiple sclerosis: A phase 1 study. Mult. Scler. J. 2011, 17, 743-754. [CrossRef]

145. Ghoul, M.; Mitri, S. The Ecology and Evolution of Microbial Competition. Trends Microbiol. 2016, $24,833-845$. [CrossRef]

146. Hibbing, M.E.; Fuqua, C.; Parsek, M.R.; Peterson, S.B. Bacterial competition: Surviving and thriving in the microbial jungle. Nat. Rev. Genet. 2010, 8, 15-25. [CrossRef]

147. Zuo, T.; Wong, S.H.; Cheung, C.P.; Lam, K.; Lui, R.; Cheung, K.; Zhang, F.; Tang, W.; Ching, J.Y.L.; Wu, J.C.Y.; et al. Gut fungal dysbiosis correlates with reduced efficacy of fecal microbiota transplantation in Clostridium difficile infection. Nat. Commun. 2018, 9, 1-11. [CrossRef]

148. Karst, S.M. The influence of commensal bacteria on infection with enteric viruses. Nat. Rev. Genet. 2016, 14, 197-204. [CrossRef] [PubMed]

149. Filyk, H.A.; Osborne, L.C. The Multibiome: The Intestinal Ecosystem's Influence on Immune Homeostasis, Health, and Disease. EBioMedicine 2016, 13, 46-54. [CrossRef] [PubMed]

150. Underhill, D.M.; Iliev, I.D. The mycobiota: Interactions between commensal fungi and the host immune system. Nat. Rev. Immunol. 2014, 14, 405-416. [CrossRef] [PubMed]

151. Kernbauer, E.; Ding, Y.; Cadwell, K. An enteric virus can replace the beneficial function of commensal bacteria. Nature 2014, 516, 94-98. [CrossRef]

152. Belkaid, Y.; Hand, T.W. Role of the microbiota in immunity and inflammation. Cell 2014, 157, 121-141. [CrossRef]

153. Arumugam, M.; Raes, J.; Pelletier, E.; Lepaslier, D.; Yamada, T.; Mende, D.R.; Fernandes, G.D.R.; Tap, J.; Bruls, T.; Batto, J.-M.; et al. Enterotypes of the human gut microbiome. Nature 2011, 473, 174-180. [CrossRef]

154. Ouwehand, A.C. A review of dose-responses of probiotics in human studies. Benef. Microbes 2017, 8, $143-151$. [CrossRef]

155. Joseph, J.; Law, C. Cross-species examination of single- and multi-strain probiotic treatment effects on neuropsychiatric outcomes. Neurosci. Biobehav. Rev. 2019, 99, 160-197. [CrossRef]

156. Kearney, S.M.; Gibbons, S.M. Designing synbiotics for improved human health. Microb. Biotechnol. 2017, 11, 141-144. [CrossRef]

(C) 2020 by the authors. Licensee MDPI, Basel, Switzerland. This article is an open access article distributed under the terms and conditions of the Creative Commons Attribution (CC BY) license (http://creativecommons.org/licenses/by/4.0/). 